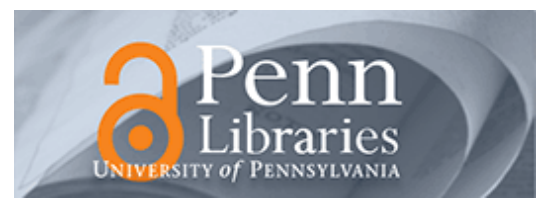

University of Pennsylvania

ScholarlyCommons

September 2004

\title{
Understanding the Decision to Enroll in Graduate School: Sex and Racial/Ethnic Group Differences
}

Laura W. Perna

University of Pennsylvania, Iperna@gse.upenn.edu

Follow this and additional works at: https://repository.upenn.edu/gse_pubs

\section{Recommended Citation}

Perna, L. W. (2004). Understanding the Decision to Enroll in Graduate School: Sex and Racial/Ethnic Group Differences. Retrieved from https://repository.upenn.edu/gse_pubs/15

Copyright The Ohio State University. Reprinted from Journal of Higher Education, Volume 75, Issue 5, September/ October 2004, pages 487-527. This material is posted here with the permission of the Ohio State University Press. Content may not be copied or emailed to multiple sites or posted to a listserv or website without the copyright holder's written permission. However, users may print, download, or email articles for individual use.

Note: At the time of publication, Laura W. Perna was affiliated with the University of Maryland, College Park. Currently (August 2006), she is a faculty member at the Graduate School of Education at the University of Pennsylvania.

This paper is posted at ScholarlyCommons. https://repository.upenn.edu/gse_pubs/15

For more information, please contact repository@pobox.upenn.edu. 


\title{
Understanding the Decision to Enroll in Graduate School: Sex and Racial/Ethnic Group Differences
}

\author{
Abstract \\ Women continue to receive fewer doctoral and first-professional degrees than men, even though women \\ receive more bachelor's degrees. The underrepresentation of women holds even after allowing for time to \\ complete an advanced degree. For example, women received $55 \%$ of the bachelor's degrees that were \\ awarded in $1994-95$ but only $44 \%$ of the doctoral degrees and $45 \%$ of the first-professional degrees that \\ were awarded five years later in 1999-00 (NCES,2002). 1 African Americans also represented smaller \\ shares of doctoral and first-professional degree recipients in 1999-00 than of bachelor's degree recipients \\ in $1994-95$ (5.0\% and $6.9 \%$ versus $7.5 \%$, NCES, 2002). Hispanics represented a smaller share of doctoral \\ degree recipients (2.9\%) but a comparable share of first-professional degrees (4.8\%) in 1999-00 than of \\ bachelor's degrees in 1994-95 (4.7\%, NCES, 2002).

\section{Comments} \\ Copyright The Ohio State University. Reprinted from Journal of Higher Education, Volume 75, Issue 5, \\ September/October 2004, pages 487-527. This material is posted here with the permission of the Ohio \\ State University Press. Content may not be copied or emailed to multiple sites or posted to a listserv or \\ website without the copyright holder's written permission. However, users may print, download, or email \\ articles for individual use. \\ Note: At the time of publication, Laura W. Perna was affiliated with the University of Maryland, College \\ Park. Currently (August 2006), she is a faculty member at the Graduate School of Education at the \\ University of Pennsylvania.
}




\section{Understanding the Decision to Enroll in Graduate School: Sex and Racial/Ethnic Group Differences}

Women continue to receive fewer doctoral and first-professional degrees than men, even though women receive more bachelor's degrees. The underrepresentation of women holds even after allowing for time to complete an advanced degree. For example, women received 55\% of the bachelor's degrees that were awarded in 1994-95 but only $44 \%$ of the doctoral degrees and $45 \%$ of the first-professional degrees that were awarded five years later in 1999-00 (NCES, 2002). ${ }^{1}$ African Americans also represented smaller shares of doctoral and firstprofessional degree recipients in 1999-00 than of bachelor's degree recipients in 1994-95 (5.0\% and 6.9\% versus 7.5\%, NCES, 2002). Hispanics represented a smaller share of doctoral degree recipients $(2.9 \%)$ but a comparable share of first-professional degrees (4.8\%) in 1999-00 than of bachelor's degrees in 1994-95 (4.7\%, NCES, 2002).

Bowen and Rudenstine (1992) offer several possible explanations for the lower representation of women, African Americans, and Hispanics among doctoral degree recipients than bachelor's degree recipients. First, non-U.S. citizens, the majority of whom are men, account for a higher share of doctoral degree recipients than bachelor's degree recipients. Second, the distribution of bachelor's degree recipients by undergraduate major field varies by sex and race/ethnicity, with women, African Americans, and Hispanics tending to major in fields in which

A Summer Research Award from the University of Maryland General Research Board (GRB) supported this research. Opinions reflect those of the author and do not necessarily reflect those of the granting agencies.

Laura W. Perna is Assistant Professor of Education Policy \& Leadership, University of Maryland, College Park.

The Journal of Higher Education, Vol. 75, No. 5 (September/October 2004)

Copyright $\odot 2004$ by The Ohio State University 
smaller shares of bachelor's degree recipients enroll in doctoral programs, such as communications. Even after taking into account these sources of the gap, however, Bowen and Rudenstine (1992) conclude that women, African Americans, and Hispanics are less likely to receive doctoral degrees. They speculate that both lower rates of doctoral program enrollment and lower rates of persisting to doctoral degree completion play a role.

Although researchers have examined sex and racial/ethnic group differences in undergraduate enrollment (e.g., Hurtado, Inkelas, Briggs, \& Rhee, 1997; Jackson, 1990; Perna, 2000; St. John \& Noell, 1989), few theoretically based, methodologically rigorous studies have explored the sources of observed sex and racial/ethnic group differences in graduate school enrollment using a nationally representative sample of students. Ethington and Smart (1986) examined sex differences in graduate enrollment using a comprehensive causal model but did not include race/ethnicity in the analyses, likely due to a small number of non-White individuals in the sample. Other research has been limited to describing the correlates of graduate enrollment for a particular group, such as Mexican-American female graduate students (Lango, 1995), AfricanAmerican doctoral recipients in sports and exercise science (King \& Chepyator-Thomas, 1996), doctoral students in higher education administration (Poock \& Love, 2001), and newly enrolled graduate students at one institution (Malaney, 1987; Stiber, 2000). A variety of conceptual approaches have been utilized to examine graduate school enrollment, including a marketing perspective (Malaney, 1987; Stiber, 2000), Hossler and Gallagher's three-stage college-choice model (Poock \& Love, 2001), Astin's theory of involvement (Lango, 1995), and Tinto's model of persistence (Ethington \& Smart, 1986).

This research contributes to our understanding of the sources of the underrepresentation of women, African Americans, and Hispanics among doctoral and professional degree recipients by examining one phase of the educational pipeline: the enrollment of bachelor's degree recipients in different types of post-baccalaureate educational programs. This study develops and tests a conceptual model that is based on an expanded econometric theoretical framework using data from a nationally representative, longitudinal survey of bachelor's degree recipients.

\section{Theoretical Framework}

Building on research that has examined racial/ethnic group differences in undergraduate enrollment (Perna, 2000), this research develops and tests the appropriateness of an expanded econometric framework for 
understanding sex and racial/ethnic group differences in post-baccalaureate enrollment. A traditional econometric perspective assumes that individuals make decisions by weighing the monetary and nonmonetary costs against the monetary and nonmonetary benefits for all possible alternatives and then selecting the alternative that maximizes utility with respect to individual preferences, tastes, and expectations (Ehrenberg, 1991; Manski \& Wise, 1983). Although the role of preferences, tastes, and expectations is generally ignored in most econometric approaches to decision making, this research explores the value of expanding a traditional econometric approach to include measures of social and cultural capital as proxies for individual expectations, preferences, tastes, and uncertainty about the graduate school enrollment decision (Paulsen \& St. John, 2002; Perna, 2000; St. John \& Asker, 2001).

After earning a bachelor's degree, an individual chooses from among the following options: enroll in graduate school either in the same or different academic field, enroll in a first-professional degree program (e.g., law, business, medicine), pursue foreign study, or work full-time (Ehrenberg, 1991). The expected benefits of enrolling in an advanced degree program include such short-term benefits as enjoyment of the learning experience and enhanced social status and such long-term benefits as higher lifetime earnings, enhanced occupational status, better working conditions, and lower probability of unemployment. The costs of enrolling in a post-baccalaureate educational program include the direct costs of attendance less any financial aid, the accumulation of additional educational debt, the cost of earnings foregone during the expected time to degree, and the need to assume a postdoctoral research position before pursuing academic employment (Ehrenberg, 1991). Some research suggests that individuals consider the benefits in their decision to pursue post-baccalaureate education. A descriptive study found that students decided to enroll in one business school to enhance not only their personal satisfaction but also their careers; students viewed enrollment as a way to become prepared for teaching and more marketable for consulting positions (Stiber, 2000).

Financial resources may influence an individual's assessment of the costs and benefits of graduate school enrollment. Students who are averse to debt and/or have already accumulated high levels of debt from their undergraduate education may be less likely to pursue graduate enrollment (Ehrenberg, 1991; McCormick, Nuñez, Shah, \& Choy, 1999). Descriptive analyses suggest that the percentage of 1992-93 bachelor's degree recipients who applied for admission to an advanced degree program by 1997 was somewhat smaller among those who borrowed for their undergraduate education than among those who did not borrow 
(38\% versus $42 \%$, McCormick et al., 1999). The results of econometric studies are contradictory, with Weiler (1991) reporting that undergraduate student loans were unrelated to the decision to enroll in a graduate program after controlling for other variables and Fox (1992) reporting that undergraduate debt had a small negative effect on enrollment in a graduate or professional program for women but was unrelated for men. Fox (1992) also concluded that higher levels of undergraduate debt may cause some students to enroll in a doctoral degree program rather than another type of post-baccalaureate program.

An individual's family resources and/or current employment may influence her or his financial resources. While some students may be able to rely on their parents to pay at least some of the costs of graduate education (Lang, 1984), other students may rely, at least in part, on the availability of an employer-supported tuition reimbursement program (Siegel \& Lajmi, 1999; Stiber, 2000). Stiber (2000) found that an employer reimbursed the costs of tuition for the majority of students who were enrolled in a business doctoral program at one institution. Tuition reimbursement likely plays a small role in the post-baccalaureate enrollment decisions of most recent college graduates, however, as descriptive analyses reveal that only $5 \%$ of $1992-93$ bachelor's degree recipients who enrolled in a graduate or professional program by 1997 utilized employer benefits to fund some portion of the costs (McCormick et al., 1999).

Women and men may assess the costs and benefits of graduate education differently. Families may be less likely to invest in the graduate education of their female children than their male children (Lang, 1984). For women, the assessment of costs and benefits may also be influenced by preferences for bearing and raising children since women who plan to take time out of the labor force for childrearing will have a shorter time horizon over which to realize the benefits. Some research suggests that sex, race, and social class are significant predictors of the rank of the graduate school that is attended (Lang, 1984) and that the stated reasons for going to graduate school vary by such demographic characteristics as sex and race, as well as citizenship and age (Malaney, 1987; Poock \& Love, 2001).

As Ehrenberg (1991) noted, individuals assess the relative costs and benefits of various alternatives based on imperfect information. The concepts of cultural and social capital may be appropriate proxies for the information that individuals have. Supporting the conclusion of St. John and Paulsen (2001) that social and cultural theories may be useful for understanding the role of nonmonetary variables in the college enrollment of different racial/ethnic groups, research has shown that measures of cultural and social capital help explain racial/ethnic group differences in undergraduate educational aspirations (Qian \& Blair, 1999) and four-year college enrollment (Perna, 2000). One way social and cultural capital may 
influence expectations, preferences, and uncertainty about graduate enrollment is through the provision of knowledge and information about the costs and benefits (DiMaggio \& Mohr, 1985; McDonough, 1997). Social and cultural capital also refer to the value that is placed on obtaining an advanced degree (DiMaggio \& Mohr, 1985; McDonough, 1997).

Like human capital and physical capital, social and cultural capital are resources that may be invested to enhance productivity (Coleman 1988) and facilitate upward mobility (DiMaggio \& Mohr 1985; Lamont \& Lareau 1988). The conceptualization of social capital has at times overlapped with the conceptualization of cultural capital (McNeal, 1999). Whereas cultural capital refers to the system of factors that is derived from one's parents that defines an individual's class status (Bourdieu \& Passeron 1977), social capital refers to social networks and the ways in which social networks and connections are sustained (Morrow 1999). In his comprehensive assessment of the origins and uses of social capital, Portes (1998) noted that social capital is acquired through an individual's relationships with other individuals, particularly through membership in social networks and other social structures. Social capital may also be understood as a tool for describing how individuals gain access to other forms of capital, including human capital and cultural capital, as well as institutional resources and support (Coleman, 1998; Portes, 1998; Morrow, 1999; Stanton-Salazar \& Dornbusch, 1995).

St. John and colleagues (Paulsen \& St. John, 2002; St. John \& Asker, 2001) proposed that the "student choice construct" be used to examine the predictors of such educational outcomes as enrollment in graduate education for individuals of different groups. According to the studentchoice construct, the educational decisions that students make are determined, at least in part, by a student's "habitus" or the system of values and beliefs that shapes an individual's views and interpretations (Paulsen \& St. John, 2002; St. John \& Asker, 2001). The student-choice construct assumes that the pattern of educational attainment is not universal but may vary across racial/ethnic and other groups (Paulsen \& St. John, 2002; St. John \& Asker, 2001).

\section{Research Methodology}

This research uses data from the 1997 follow-up to the Baccalaureate and Beyond survey of 1992/93 bachelor's degree recipients (B\&B:93/97) to address the following research questions:

1. Does controlling for measures of cultural and social capital improve the explanatory power of a traditional econometric model of post-baccalaureate enrollment? 
2. How does the likelihood of post-baccalaureate enrollment vary between women and men bachelor's degree recipients? What are the sources of the observed sex differences in post-baccalaureate enrollment?

3. How does the likelihood of post-baccalaureate enrollment vary by race/ethnicity? What are the sources of the observed racial/ethnic group differences in post-baccalaureate enrollment?

Sponsored by the National Center for Education Statistics (NCES), B\&B:93/97 tracks the experiences of individuals who received their bachelor's degree during the 1992-93 academic year, with follow-ups in 1994 and 1997. For the base year, data were collected as part of another NCES survey, the 1993 National Postsecondary Student Aid Survey (NPSAS:93). The NPSAS:93 utilized a two-stage stratified sample design in which 1,243 eligible postsecondary educational institutions were first identified, and then students attending the $88 \%$ of the institutions that responded with lists of students were selected (Green, Myers, Veldman, \& Pedlow, 1999). Data were collected from $73 \%$ of the 16,316 students who were initially identified as bachelor's degree recipients. Subsampling of nonrespondents increased the sample size to 12,478 . Further review of the interview and transcript data revealed that only 11,192 of the cases were eligible for inclusion in B\&B (Green et al., 1999). The B\&B:93/97 includes data for 9,274 students, or $83 \%$ of the 11,192 students in the base-year sample, who responded to all three data collections (McCormick et al., 1999). The sample used in this study is limited to the 9,241 cases that have data for the dependent variable, highest-degree program enrolled in by 1997.

The B\&B:93/97 panel weight is appropriate for approximating the population of 1992-93 bachelor's degree recipients in the longitudinal sample. To minimize the influence of large sample sizes on standard errors while also correcting for the oversampling of some groups, each case is weighted by the B\&B:93/97 panel weight divided by the average weight for the sample (Thomas \& Heck, 2001). To correct for the design effects of the B\&B:93/97 that are associated with the nested nature of the data (i.e., bachelor's degree recipients selected from within selected institutions), a rigorous threshold of statistical significance $(\mathrm{p}<.001)$ is used to interpret the results (Thomas \& Heck, 2001).

\section{Conceptual Model}

Building on the suggestion of others (Paulsen \& St. John, 2002; Perna, 2000; St. John \& Asker, 2001) that traditional econometric 
frameworks be expanded to include aspects of social and cultural theories, the conceptual model that is used in this study assumes that the decision to enroll in a post-baccalaureate program is a function of sex, race/ethnicity, expected costs and benefits, financial and academic resources, and cultural and social capital. Five racial/ethnic groups are considered in the analyses: Asian, Black, Hispanic, White (reference group), and other. The "other" racial/ethnic group is comprised of American Indians/Alaskan Natives, nonresident aliens, and students with unknown or other race/ethnicity, categories with too few cases to be examined separately. ${ }^{2}$

\section{Expected costs and benefits}

The costs of attending graduate school include the direct costs of enrolling less some amount of financial aid and the opportunity cost of enrolling, as measured by foregone earnings. Because graduate and professional enrollment is assumed to be based on a national market rather than state or regional markets as with undergraduate enrollment, all bachelor's degree recipients are assumed to face the same direct costs of attendance. Thus, the direct costs of graduate enrollment are not included in the analyses.

The major field of the bachelor's degree is used as a proxy for foregone earnings and other labor market opportunities. Foregone earnings are typically measured by starting salaries for bachelor's degree recipients who enter the workforce rather than enroll in additional education (Weiler, 1991). Following the example of Andrieu and St. John (1993), who grouped fields into three groups based on the earnings of graduates, published data describing starting salaries by major field were obtained. The data show that median annual starting salaries for 1993 bachelor's degree recipients who were working full-time in April 1997 varied by major field, ranging from a high of $\$ 44,524$ for those with engineering majors to a low of $\$ 26,513$ for those with education majors (McCormick et al., 1999). Based on the differences in starting salaries across fields, undergraduate major fields are organized into four roughly equal-sized groups reflecting lowest to highest salaries: lowest quartile (education, history, and psychology, $32 \%$ of cases), second quartile (humanities, social sciences, public affairs and social services, and other, $26 \%$ of cases), third quartile (business and management, 23\% of cases), and highest quartile (math and other sciences, health professions, and engineering, $19 \%$ of cases, reference group).

According to the economic theory of human capital (Becker, 1962), individuals are expected to consider the time horizon, or the number of 
years over which an increase in earnings may be realized, in their calculations of the lifetime increase in earnings that may result from post-baccalaureate enrollment. Individuals who delay entry into college after graduating from high school or require longer than four years to complete a bachelor's degree may be less likely to invest in additional education in part because they have a shorter time period over which to realize an increase in lifetime earnings. Delaying college entry is measured by whether the individual enrolled in college within four months of graduating from high school (yes or no). Because of the nonnormal distribution, the number of years required to complete the bachelor's degree after first enrolling in college is recoded into four substantively meaningful groups: no more than four years (35\% of cases); five years (28\% of cases); six to seven years (16\% of cases); and more than seven years ( $21 \%$ of cases, reference category).

The assessment of the costs and benefits may depend on a bachelor's degree recipient's marital status and parental status. Marital status is measured as married rather than not married in 1993. Parental status is measured by whether the student had any dependents in 1993 (yes or no).

\section{Financial and academic resources}

Financial resources may also influence the assessment of the benefits and costs of post-baccalaureate enrollment (Becker, 1962). One measure of financial resources is the amount of undergraduate educational debt. Because about one-half of 1992-93 bachelor's degree recipients did not borrow to pay the costs of their undergraduate education and because the distribution of the amount borrowed is positively skewed even when only individuals who borrowed are considered, undergraduate borrowing is treated as an ordinal variable: did not borrow (54\% of cases); borrowed less than $\$ 4,000$ ( $10 \%$ of cases); borrowed between $\$ 4,000$ and $\$ 7,999$ (12\% of cases); borrowed between $\$ 8,000$ and $\$ 12,599$ (12\% of cases); and borrowed $\$ 12,600$ or more (12\% of cases, reference category). The levels reflect the lowest to the highest quartiles of the amount borrowed among individuals who borrowed.

Because an individual's parents may be a source of financial support for post-baccalaureate enrollment, the income and dependency status of the individual in 1992-93, when the bachelor's degree was received, is an additional measure of financial resources. Following the example of Andrieu and St. John (1993), dependency status and income are both considered in the analyses. The seven dependency status and income categories, collapsed from the 16 categories in the B\&B:93/97 dataset, are: dependent with family income below $\$ 30,000$; dependent with fam- 
ily income between $\$ 30,000$ and $\$ 50,000$; dependent with family income between $\$ 50,000$ and $\$ 70,000$; dependent with family income over $\$ 70,000$; independent with income below $\$ 10,000$; independent with income between $\$ 10,000$ and $\$ 30,000$; and independent with income over $\$ 30,000$ (reference category).

From an econometric perspective, academic ability not only represents an individual's initial stock of human capital, but also influences an individual's assessment of the likelihood of completing a program and realizing the expected benefits (Catsiapis, 1987). Academic achievement is measured by cumulative undergraduate grade-point average and SAT/ACT quartile. The variable on the B\&B:93/97 dataset measuring cumulative undergraduate grade-point average has the following categories: no higher than Bs and Cs; mostly Bs; As and Bs; and mostly As (reference category). SAT/ACT quartile reflects the SAT quartile if the SAT quartile is available and the ACT quartile if the SAT quartile is not. A fifth category, did not take SAT or ACT, is also included.

\section{Cultural and social capital}

Measures of cultural and social capital are included to reflect an individual's preferences and tastes for graduate education (Perna, 2000), as well as the system of values and beliefs in which an individual is situated (Paulsen \& St. John, 2002; St. John \& Asker, 2001). Two measures of cultural capital are parental educational attainment and whether the language that is most often spoken in the home is English (yes or no). While some analyses utilize a composite measure of socioeconomic status, including separate measures for such components as family income (included in this study as a measure of financial resources) and parental education (included here as a measure of cultural and social capital) may be particularly important for understanding racial/ethnic group differences in enrollment (Paulsen \& St. John, 2002; St. John \& Asker, 2001). Parental educational attainment is measured by the highest level of education that was attained by either parent, ranging from no more than high school to a professional or doctoral degree (reference category).

The analyses include several measures of the extent to which an individual values additional education. On the base-year component of the B\&B:93/97 survey, students reported whether each of 11 items was important (yes or no). Exploratory factor analysis revealed that four factors explained 53\% of the variance in these 11 items. Two factors, valuing financial success (comprised of being well off financially and owning one's own business) and valuing family ties (comprised of living close to parents or relatives, not wanting to get away from home, and having 
children) had low alpha reliability coefficients $(\alpha=.325$ and $\alpha=.310$, respectively) and thus are not included in the analyses. A third factor, being successful in the labor market, is included in the analyses. Comprised of being successful in the line of work (factor loading $=0.750$ ), finding steady work (0.754), and having enough leisure time to enjoy own interests $(0.754)$, this factor has an alpha reliability coefficient of 0.644 . The alpha reliability coefficient for the fourth factor, becoming a leader, is low $(\alpha=0.415)$ and could not be increased by removing any of the items from the composite. Because the items appear to reflect the extent to which an individual values outcomes that may result from graduate education, each of the three questionnaire items (influencing the political structure, being a leader in the community, and becoming an authority in a given field), is included in the analyses.

The base year of the B\&B:93/97 included 12 additional questionnaire items reflecting the importance of various aspects of future work. Exploratory factor analysis showed that four factors explained 54\% of the variance in the 12 items. The first factor, quality of work life, is comprised of seven items: independent work (factor loading $=0.741$ ), freedom to make own decisions (0.716), time for extracurricular activity (0.709), allow roots to be established (0.591), interaction with people (0.532), great deal of travel (0.448), and prestige and status (0.323). The factor is reasonably reliable $(\alpha=0.72)$ and is included in the analyses.

Only one questionnaire item loaded on the second factor, the importance of doing intellectually challenging work. Because this item reflects a value that appears to be consistent with graduate education, the single questionnaire item is included in the analyses. The two other factors, valuing income and security and valuing interesting work, had low alpha-reliability coefficients ( $\alpha=.46$ and $\alpha=.13$, respectively) and thus were not included in the analyses.

Social capital may be derived from the relationship between the bachelor's degree recipient and his or her parents (Portes, 1998; McNeal, 1999). In this study, parental involvement is measured by the total direct monetary contribution that bachelor's degree recipients received from their parents for their undergraduate education. Because nearly one-half of the cases reported no direct contribution from their parents and, among individuals with some contribution, the distribution is positively skewed, the following categories are included in the analyses: no support (44\% of the cases), less than $\$ 1,500$ (13\% of the cases), $\$ 1,500$ to $\$ 3,999$ ( $15 \%$ of the cases), $\$ 4,000$ to $\$ 7,999$ (13\% of the cases), and $\$ 8,000$ or more (reference category, $16 \%$ of the cases). The categories reflect quartiles of support among individuals who received some amount of support. 
The existence of other social networks that may promote graduate enrollment is measured by such characteristics of the bachelor's degreegranting institution as Carnegie classification, tuition, and location. The Carnegie classification system reflects, at least in part, the relative emphasis of the institution on research and graduate education. The following Carnegie classes are included in the analyses: research I, other doctoral-granting, comprehensive I, liberal arts I, and other (e.g., liberal arts II, specialized). Tuition, one measure of institutional quality (McPherson \& Winston, 1993; Perna, 1998), is measured by the tuition and fees that are typically charged by the institution for full-time, full-year attendance. Because the variable is positively skewed, tuition is recoded into quartiles. Location, a measure of the breadth of the peer network, is measured by whether the student received the bachelor's degree from an institution in the student's home state, home region, or outside the student's home region (reference category). Whether an individual attended a two-year college prior to receiving the bachelor's degree (yes or no) is also included.

\section{Analyses}

The dependent variable measures the highest degree program in which a student was enrolled by 1997 , four to five years after earning the bachelor's degree. Descriptive analyses are used to compare the characteristics of bachelor's degree recipients in each of five enrollment categories: did not enroll, enrolled in a submaster's level program (e.g., certificate, associate's degree, or bachelor's degree program), enrolled in a master's degree program, enrolled in a first-professional degree program (e.g., MBA, law, or medicine), and enrolled in a doctoral degree program. Descriptive analyses are also used to compare the characteristics of women and men bachelor's degree recipients and bachelor's degree recipients of different racial/ethnic groups.

Because of the categorical nature of the dependent variable, a multinomial logit model, a special case of the general log-linear model, is used to examine the relationships between sex and race/ethnicity and postbaccalaureate enrollment status after controlling for other variables. Multinomial logit models estimate the log-odds of one outcome occurring relative to the baseline category. In these analyses, no enrollment by 1997 is the baseline category. If the baseline category is $j$, the model for the $i^{\text {th }}$ category (e.g., enrollment in a master's degree program) is:

$$
\log \left(\mathrm{P}_{i} / \mathrm{P}_{j}\right)=B_{i 0}+B_{i 1} \mathrm{X}_{1}+B_{i 2} \mathrm{X}_{2}+\ldots+B_{i p} \mathrm{X}_{p}
$$


The logistic coefficients that result from this equation may be interpreted as the change in log odds that is associated with a one-unit change in the independent variable. The interpretation of the multinomial logit coefficients is facilitated by the use of odds-ratios, as described by the following equation:

$$
\mathrm{P}_{i} / \mathrm{P}_{j}={ }_{\mathrm{e}} B_{i 0}+B_{i 1} \mathrm{X}_{1}+\ldots+B_{i p} \mathrm{X}_{p}={ }_{\mathrm{e}} B_{i 0 \mathrm{e}} B_{i 1} \mathrm{X}_{1} \ldots \mathrm{e} B_{i p} \mathrm{X}_{p}
$$

The odds-ratio represents the change in the odds of a particular type of enrollment relative to the reference category (not enrolled) that is associated with a one-unit change in a particular independent variable holding constant all other variables (Peng, So, Stage, \& St. John, 2002). An odds-ratio greater than one represents an increase in the likelihood of enrolling in a particular type of post-baccalaureate program relative to not enrolling, whereas an odds-ratio less than one represents a decrease in the likelihood of enrolling in the program.

The two continuous variables, the importance of labor market success and the importance of the quality of work life, are entered into the model as covariates. The test of whether a parameter is different from zero is based on two statistics that are generated by SPSS version 10.0: the likelihood ratio test and the Wald statistic (Peng et al., 2002). The likelihood ratio test is used to determine if a parameter is related to the probability of post-baccalaureate enrollment overall, and, if so, the Wald statistic is used to determine if a parameter is related to particular types of postbaccalaureate enrollment.

As suggested by others (Cabrera, 1994; Peng et al., 2002), several indicators are used to evaluate the model. While not completely comparable to the $\mathrm{R}^{2}$ in ordinary least-squares regression, the McFadden pseudo- $\mathrm{R}^{2}$ indicates the strength of the relationship between the outcome variable and the independent variables (Peng et al., 2002). The percentage of cases that is correctly classified, the ratio of scaled deviance $\left(G^{2}\right)$ to its degrees of freedom, and the model chi-square provide three additional indicators of model fit (Cabrera, 1994; Peng et al., 2002). The model chi-square tests the difference in the $-2 \log$ likelihood between the final model and a model that includes the intercept only. The change in scaled deviance provides an indication of the improvement in fit that is associated with the inclusion of additional predictors (Cabrera, 1994).

As noted by Peng and colleagues (2002), "examining the possibility of interaction between predictors is an essential step in model building strategies" (p. 267). Because the theoretical framework and prior research (Ethington \& Smart, 1986; Hearn, 1987; Fox, 1992) suggest that 
the process of enrolling in graduate school is different for women than for men, interaction terms between female and each independent variable are entered into the final block of the multinomial logit analyses. As described below, several of the interactions between sex and each independent variables are statistically significant. To facilitate the interpretation of the interactions, separate multinomial logit analyses are conducted for women and men.

\section{Missing data}

The analyses are limited by the magnitude of missing data. The variables with the largest shares of missing data are those measuring the direct contribution of the parent to the student's education (17\% of the cases) and an individual's values toward additional education and aspects of future work (14\% of the cases). Listwise deletion would reduce the analytic sample from 9,241 cases to 5,340 (adjusted weighted sample sizes) and result in a sample that is not representative of the population of 1992-93 bachelor's degree recipients. Although women and men are equally likely to be excluded because of listwise deletion of missing data, the likelihood of being excluded varies by racial/ethnic group, with missing data more common among individuals of other or unknown race/ethnicity than among the sample as a whole. Individuals who enrolled in a doctoral program also appear to be more likely than other students to be missing data for at least one variable.

Although researchers disagree on the minimum number of cases that is required per independent variable, researchers generally agree that larger sample sizes will generate more stable parameter estimates and more accurate $\chi^{2}$ distributions (Peng et al., 2002). To avoid the substantial reduction in sample size that would result from listwise deletion of missing data and to account for the tendency of cases to be missing data for more than one independent variable, the analyses include a single independent variable that reflects a "tendency to have missing data" (Cohen \& Cohen, 1983). This variable is calculated as the number of independent variables on which data are missing. Mean scores are imputed for cases that are missing data for either of the two continuous variables. While preserving sample sizes, this treatment of missing values may result in an underestimation of the standard errors. Therefore, the use of a rigorous threshold of statistical significance $(\mathrm{p}<.001)$ not only corrects for the design effects (described above) but also reduces the possibility that the parameters for these variables falsely appear to be statistically significant (Type I error). 


\section{Findings}

\section{Characteristics of Bachelor's Degree Recipients Who Pursue Additional Education}

About one-half (48\%) of 1992-93 bachelor's degree recipients enrolled in some type of post-baccalaureate educational program by 1997. Table 1 shows that about one-fifth (18\%) enrolled in a program that was below the master's degree level (e.g., certificate, non-degree, associate's degree, bachelor's degree) and one-fifth (20\%) enrolled in a master's degree program. Only $7 \%$ enrolled in a first-professional degree program and just $3 \%$ enrolled in a doctoral degree program.

Doctoral degree enrollment includes too few cases (adjusted weighted $n=272$ ) to be included as a separate category in the multinomial logit analyses. Descriptive analyses ${ }^{3}$ suggest that bachelor's degree recipients

TABLE 1

Distribution of 1993 Bachelor's Degree Recipients by Post-Baccalaureate Enrollment by 1997, Sex, and Race/Ethnicity

\begin{tabular}{|c|c|c|c|c|c|c|c|c|}
\hline & $\begin{array}{c}\text { Total } \\
\mathrm{n}\end{array}$ & $\%$ & $\begin{array}{c}\text { No } \\
\text { Enrollment }\end{array}$ & $\begin{array}{l}\text { Less than } \\
\text { Master's }\end{array}$ & $\begin{array}{l}\text { Master's } \\
\text { Program }\end{array}$ & $\begin{array}{l}\text { Doctoral } \\
\text { Program }\end{array}$ & $\begin{array}{c}\text { First- } \\
\text { Professional }\end{array}$ & $\begin{array}{l}\text { Statistical } \\
\text { Difference }\end{array}$ \\
\hline \multicolumn{9}{|l|}{ Total } \\
\hline $\mathrm{n}$ & 9,241 & & 4,803 & 1,682 & 1,824 & 272 & 660 & \\
\hline$\%$ & & $100 \%$ & 52.0 & 18.2 & 19.7 & 2.9 & 7.1 & \\
\hline Sex & & & & & & & & $\phi=0.13$ \\
\hline Women & 5,051 & $100 \%$ & 50.3 & 19.9 & 22.7 & 2.1 & 5.0 & \\
\hline Men & 4,190 & $100 \%$ & 54.0 & 16.2 & 16.2 & 3.9 & 9.7 & \\
\hline Race/Ethnicity & & & & & & & & $\phi=0.10$ \\
\hline White & 7,545 & $100 \%$ & 52.8 & 18.2 & 19.3 & 3.1 & 6.6 & \\
\hline Black & 552 & $100 \%$ & 53.0 & 16.9 & 21.6 & 2.0 & 6.5 & \\
\hline Hispanic & 430 & $100 \%$ & 48.8 & 20.2 & 20.5 & 2.8 & 7.7 & \\
\hline Asian & 362 & $100 \%$ & 46.8 & 21.8 & 13.5 & 2.2 & 15.7 & \\
\hline Other/Unknown & 352 & $100 \%$ & 40.8 & 14.7 & 31.2 & 2.8 & 10.5 & \\
\hline Sex \& Race & & & & & & & & $\phi=0.18$ \\
\hline White women & 4,051 & $100 \%$ & 50.5 & 20.0 & 22.8 & 2.3 & 4.4 & \\
\hline White men & 3,494 & $100 \%$ & 55.6 & 16.0 & 15.3 & 4.0 & 9.2 & \\
\hline Black women & 373 & $100 \%$ & 51.3 & 17.5 & 22.6 & 1.3 & 7.3 & \\
\hline Black men & 179 & $100 \%$ & 56.2 & 15.7 & 19.7 & 3.4 & 5.1 & \\
\hline Hispanic women & 255 & $100 \%$ & 51.4 & 20.0 & 21.6 & 1.6 & 5.5 & \\
\hline Hispanic men & 174 & $100 \%$ & 45.1 & 20.6 & 18.9 & 4.6 & 10.9 & \\
\hline Asian women & 175 & $100 \%$ & 48.9 & 25.3 & 14.4 & 2.3 & 9.2 & \\
\hline Asian men & 188 & $100 \%$ & 45.5 & 18.7 & 12.3 & 2.1 & 21.4 & \\
\hline Other women & 197 & $100 \%$ & 43.4 & 17.2 & 27.8 & 1.5 & 10.1 & \\
\hline Other men & 155 & $100 \%$ & 37.7 & 11.7 & 35.7 & 3.9 & 11.0 & \\
\hline
\end{tabular}

NOTE: The statistical difference column shows the strength of the relationship, calculated using the following formula: $\phi=\sqrt{ }\left(\chi^{2} / \mathrm{n}\right)$. A $\phi$ that is below 0.3 represents a "small" effect size.

SOURCE: Analyses of B\&B:93/97 
who enroll in doctoral degree programs are no different from other bachelor's degree recipients in terms of the importance of doing intellectually challenging work, the importance of labor market success, the importance of work life quality, and the importance of becoming an authority in the field. Bachelor's degree recipients who enroll in doctoral degree programs appear to be different from other bachelor's degree recipients in terms of their undergraduate major field, cumulative undergraduate grade-point average, Carnegie classification of bachelor's degree-granting institution, and location of bachelor's degree-granting institution. Individuals who enroll in doctoral degree programs appear to be similar to individuals who enroll in first-professional degree programs and different from those in other groups in terms of such variables as the total amount borrowed for their undergraduate education, marital status in 1993, number of dependents in 1993, income and dependency status, SAT/ACT quartile, age, parents' education, tuition at the undergraduate institution, and total direct monetary support from parents for undergraduate education. Despite these similarities, doctoral enrollees are excluded from the multinomial logit analyses because of the number of differences between doctoral program enrollees and other bachelor's degree recipients and because of the absence of a theoretical rationale for combining doctoral enrollees with first-professional enrollees, the group to which doctoral enrollees seem to be most similar.

\section{Contribution of Measures of Cultural and Social Capital to the Model}

The multinomial logistic regression analyses suggest that adding measures of cultural and social capital to traditional econometric measures improves the explanatory power of a model of post-baccalaureate enrollment. Table 2 shows that the ratio of deviance to degrees of freedom increases from 2.00 to 2.17 , approaching the 2.5 minimum threshold that some researchers have proposed (Peng et al., 2002), when measures of cultural and social capital are added to a model that includes measures of expected costs and benefits and financial and academic resources. The change in defiance $(-2 \log$ likelihood) that is associated with the addition of measures of cultural and social capital to the model suggests a statistically significant improvement in fit. The percentage of cases that is correctly classified also increases somewhat when measures of cultural and social cultural capital are added to the model. Table 2 shows that adding measures of cultural and social capital to the measures of sex, race/ethnicity, expected costs and benefits, and financial and academic resources increases the percentage of cases that is correctly classified for submaster's level enrollment (from 1\% to 2\%) and master's degree enrollment (from 15\% to 19\%). 
TABLE 2

Change in the Relationships Between Sex and Race/Ethnicity and Post-Baccalaureate Enrollment When Differences in Resources and Cultural and Capital Are Taken Into Account

\begin{tabular}{|c|c|c|c|c|c|c|c|c|c|}
\hline \multirow[b]{2}{*}{ Characteristic } & \multicolumn{3}{|c|}{$\begin{array}{c}\text { Model } 1 \\
\text { Sex \& Race }\end{array}$} & \multicolumn{3}{|c|}{$\begin{array}{c}\text { Model } 2 \\
\text { Academic \& Financial Resources }\end{array}$} & \multicolumn{3}{|c|}{$\begin{array}{c}\text { Model } 3 \\
\text { Cultural and Social Capital }\end{array}$} \\
\hline & B & Std. Error & $\operatorname{Exp}(B)$ & B & Std. Error & $\operatorname{Exp}(B)$ & B & Std. Error & $\operatorname{Exp}(B)$ \\
\hline \multicolumn{10}{|l|}{ Sub-Master's level } \\
\hline Female & 0.284 & 0.058 & $1.328 * * *$ & 0.196 & 0.062 & $1.217 * *$ & 0.214 & 0.062 & $1.239 * *$ \\
\hline Black & -0.114 & 0.123 & 0.893 & -0.054 & 0.129 & 0.947 & -0.036 & 0.131 & 0.964 \\
\hline Hispanic & 0.165 & 0.132 & 1.180 & 0.113 & 0.136 & 1.119 & 0.313 & 0.148 & $1.368^{*}$ \\
\hline Asian & 0.307 & 0.140 & $1.359 *$ & 0.346 & 0.143 & $1.413 *$ & 0.569 & 0.158 & $1.766^{* * * *}$ \\
\hline Other & -0.031 & 0.167 & 0.969 & 0.116 & 0.173 & 1.123 & 0.201 & 0.177 & 1.222 \\
\hline \multicolumn{10}{|l|}{ Master's degree } \\
\hline Female & 0.396 & 0.057 & $1.486^{* * * *}$ & 0.159 & 0.062 & $1.173 *$ & 0.183 & 0.063 & $1.201 * *$ \\
\hline Black & 0.049 & 0.114 & 1.050 & 0.457 & 0.123 & $1.579 * * *$ & 0.468 & 0.125 & $1.596 * * *$ \\
\hline Hispanic & 0.089 & 0.132 & 1.093 & 0.208 & 0.139 & 1.231 & 0.367 & 0.149 & $1.444^{*}$ \\
\hline Asian & -0.258 & 0.166 & 0.772 & -0.190 & 0.172 & 0.827 & -0.041 & 0.185 & 0.960 \\
\hline Other & 0.526 & 0.133 & $1.693 * * *$ & 0.571 & 0.145 & $1.770 * * *$ & 0.535 & 0.150 & $1.707 * * *$ \\
\hline \multicolumn{10}{|l|}{ Professional degree } \\
\hline Female & -0.593 & 0.086 & $0.553 * * *$ & -0.733 & 0.093 & $0.480 * * *$ & -0.690 & 0.095 & $0.501 * * *$ \\
\hline Black & 0.059 & 0.185 & 1.061 & 0.881 & 0.200 & $2.414 * * *$ & 0.901 & 0.203 & $2.462 * * *$ \\
\hline Hispanic & 0.248 & 0.196 & 1.281 & 0.699 & 0.208 & $2.011 * *$ & 0.765 & 0.220 & $2.150 * *$ \\
\hline Asian & 0.904 & 0.164 & $2.468 * * *$ & 0.946 & 0.178 & $2.576 * * *$ & 0.873 & 0.201 & $2.393 * * *$ \\
\hline Other & 0.398 & 0.196 & $1.489 *$ & 0.516 & 0.218 & $1.676^{*}$ & 0.481 & 0.223 & $1.617 *$ \\
\hline-2 log likelihood, df & 1,188 & $18 * * *$ & & 17,735 & $96^{* * *}$ & & 19,084 & $171 * * *$ & \\
\hline Model fit-Pearson $\chi^{2}$ & 503 & $297 * * *$ & & 23,311 & $22,296 * * *$ & & 27,312 & $26,607 * *$ & \\
\hline Pseudo $\mathrm{R}^{2}$ (McFadden) & 0.02 & & & 0.08 & & & 0.09 & & \\
\hline $\mathrm{G}^{2} / \mathrm{df}$ & 0.13 & & & 2.00 & & & 2.17 & & \\
\hline
\end{tabular}




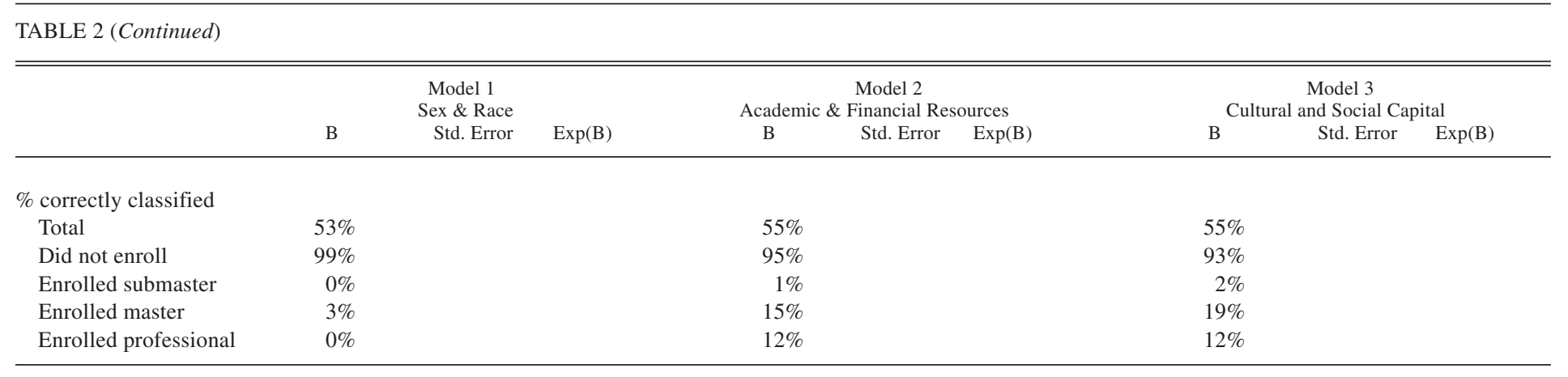

NOTES: Enrollment by 1997 is relative to no enrollment.

The reference groups are male for female and White, not Hispanic for each racial/ethnic group.

The control variables in model 2 are starting salary, delay enrollment, time to bachelor's degree, martial and parental status, income and dependency status, undergraduate borrowing, undergraduate grades, and SAT/ACT scores.

The control variables in model 3 are those in model 2 plus parents' education, primary language, importance of job success, becoming a leader, becoming an authority, influencing the political structure, worklife quality, and doing intellectually challenging work, parental support for education, Carnegie class, tuition quartile, location, and attended two-year institution.

*** $\mathrm{p}<.001, \quad * * \mathrm{p}<.01, \quad * \mathrm{p}<.05$

SOURCE: Analyses of B\&B:93/97 
The likelihood ratio tests show the particular measures of cultural and social capital that are related to post-baccalaureate enrollment. Table 3 shows that, in terms of cultural capital, parental education is a statistically significant predictor of post-baccalaureate enrollment. In terms of values, only the reported importance of influencing the political structure is related to post-baccalaureate enrollment. Two measures of social networks and relationships are related to the likelihood of post-baccalaureate enrollment: the Carnegie classification of the undergraduate institution and attendance at a two-year institution.

TABLE 3

Likelihood Ratio Tests for Variables that are Included in the Multinomial Logit Analyses

\begin{tabular}{|c|c|c|c|c|c|c|}
\hline Characteristic & $\begin{array}{c}\text { Total } \\
\text { Chi-Square }\end{array}$ & df & $\begin{array}{l}\text { Women } \\
\text { Chi-Square }\end{array}$ & df & $\begin{array}{c}\text { Men } \\
\text { Chi-Square }\end{array}$ & $\mathrm{df}$ \\
\hline Female & 91 & $3 * * *$ & & & & \\
\hline Black & 29 & $3 * * *$ & 30 & $3 * * *$ & 6 & 3 \\
\hline Hispanic & 15 & $3 * *$ & 2 & 3 & 16 & $3 * *$ \\
\hline Asian & 29 & $3 * * *$ & 10 & $3 *$ & 21 & $3 * * *$ \\
\hline Other & 14 & $3 * *$ & 4 & 3 & 12 & $3 * *$ \\
\hline Starting salary & 421 & $9 * * *$ & 215 & $9 * * *$ & 222 & $9 * * *$ \\
\hline Delay enrollment & 1 & 3 & 3 & 3 & 0 & 3 \\
\hline Time to BA & 67 & $9 * * *$ & 20 & $9 *$ & 61 & $9 * * *$ \\
\hline Marital status & 10 & $3 *$ & 10 & $3 *$ & 9 & $3 *$ \\
\hline Any dependents & 2 & 3 & 4 & 3 & 0 & 3 \\
\hline Dependency \& income & 58 & $18 * * *$ & 46 & $18 * * *$ & 35 & $18 *$ \\
\hline Amount borrowed & 21 & 12 & 20 & 12 & 15 & 12 \\
\hline Grades & 148 & $9 * * *$ & 54 & $9 * * *$ & 102 & $9 * * *$ \\
\hline SAT/ACT quartile & 87 & $12 * * *$ & 62 & $12 * * *$ & 39 & $12 * * *$ \\
\hline Parents' education & 49 & $12 * * *$ & 37 & $12 * * *$ & 29 & $12 * *$ \\
\hline English spoken at home & 13 & $3^{* *}$ & 16 & $3^{* *}$ & 1 & 3 \\
\hline Important: job success & 3 & 3 & 4 & 3 & 2 & 3 \\
\hline Important: work life quality & 3 & 3 & 17 & $3 * *$ & 2 & 3 \\
\hline Important: leader & 13 & $3 * *$ & 15 & $3 * *$ & 1 & 3 \\
\hline Important: authority & 1 & 3 & 4 & 3 & 5 & 3 \\
\hline Important: political & 19 & $3 * * *$ & 14 & $3 * *$ & 6 & 3 \\
\hline Important: intellectual & 4 & 3 & 8 & 3 & 3 & 3 \\
\hline Direct support from parents & 29 & $12 * *$ & 24 & $12 *$ & 20 & 12 \\
\hline Carnegie class & 47 & $12 * * *$ & 43 & $12 * * *$ & 35 & $12 * *$ \\
\hline Tuition quartile & 20 & $9 *$ & 7 & 9 & 24 & $9 * *$ \\
\hline Region of institution & 19 & $6 * *$ & 11 & 6 & 20 & $6 * *$ \\
\hline Attended 2-year & 20 & $3 * * *$ & 17 & $3 * *$ & 4 & 3 \\
\hline Number missing items & 148 & $3 * * *$ & 115 & $3 * * *$ & 53 & $3 * * *$ \\
\hline Intercept & 0 & 0 & 0 & 0 & 0 & 0 \\
\hline
\end{tabular}

$* * * \mathrm{p}<.001, \quad * * \mathrm{p}<.01, \quad * \mathrm{p}<.05$

SOURCE: Analyses of B\&B:93/97 


\section{Sex Differences in Post-Baccalaureate Enrollment}

Descriptive analyses show that, although the effect is small in magnitude, the pattern of post-baccalaureate enrollment is different for women than for men. Table 1 suggests that higher shares of women than men enroll in programs below the master's level (20\% versus $16 \%)$ and at the master's level programs (23\% versus $16 \%$ ) and that smaller shares of women than men enroll in doctoral (2\% versus $4 \%)$ and first-professional (5\% versus $10 \%)$ programs.

Consistent with the descriptive analyses, the multinomial logit analyses show that, after controlling only for race/ethnicity, women are more likely than men to enroll in either a submaster's level program (odds ratios $=1.33$ ) or a master's degree program (odds ratio $=1.49$ ), but less likely than men to enroll in a first-professional degree program (odds ratio $=0.55$ ) relative to not enrolling by 1997 . Table 2 shows that adding controls for expected costs and benefits and financial and academic resources eliminates the observed sex difference in the likelihood of enrolling in either a submaster's level program or a master's degree program relative to not enrolling. The odds of enrolling in enrolling in either a submaster's level program or a master's degree program continue to be comparable for women and men when measures of cultural and social capital are also taken into account. In contrast, the odds of enrolling in a first-professional program are lower for women than for men (odds ratio $=0.50$ ) even after controlling for expected costs and benefits and financial and academic resources (model 2) and measures of cultural and social capital (model 3).

A review of the statistically significant interactions (available from the author on request) suggests that the model of post-baccalaureate enrollment is different for women and men bachelor's degree recipients. Female interacted with three independent variables: Black, starting salary, and Carnegie classification of the undergraduate institution. Separate analyses for women and men suggest that the model of post-baccalaureate enrollment that was developed for this study is somewhat better at predicting the likelihood of submaster's level enrollment for men than for women, with 7\% of the cases correctly classified for men and $4 \%$ for women (Table 4), better at predicting the likelihood of master's degree enrollment for women than for men, with $23 \%$ of the cases correctly classified for women and $18 \%$ for men (Table 5), and better at predicting the likelihood of professional degree enrollment for men than women, with $19 \%$ of the cases correctly classified for men and $11 \%$ for women (Table 6). 
TABLE 4

Predictors of Highest Enrollment by 1997 For Male and Female 1992/93 Bachelor's Degree Recipients Using Multinomial Logistic Regression: Sub-Master's Level Enrollment

\begin{tabular}{|c|c|c|c|c|c|c|c|c|c|}
\hline Characteristic & B & $\begin{array}{l}\text { Total } \\
\text { Std. } \\
\text { Error }\end{array}$ & $\begin{array}{l}\text { Odds- } \\
\text { ratio }\end{array}$ & B & $\begin{array}{l}\text { Women } \\
\text { Std. } \\
\text { Error }\end{array}$ & $\begin{array}{l}\text { Odds- } \\
\text { ratio }\end{array}$ & B & $\begin{array}{l}\text { Men } \\
\text { Std. } \\
\text { Error }\end{array}$ & $\begin{array}{l}\text { Odds- } \\
\text { ratio }\end{array}$ \\
\hline Female & 0.214 & 0.062 & $1.239 * *$ & & & & & & \\
\hline \multicolumn{10}{|l|}{ Male (reference) } \\
\hline Black & -0.036 & 0.131 & 0.964 & -0.083 & 0.161 & 0.920 & 0.164 & 0.232 & 1.178 \\
\hline Hispanic & 0.313 & 0.148 & $1.368^{*}$ & 0.139 & 0.192 & 1.149 & 0.566 & 0.240 & $1.762 *$ \\
\hline Asian & 0.569 & 0.158 & $1.766 * * *$ & 0.572 & 0.218 & $1.772 * *$ & 0.602 & 0.238 & $1.827 *$ \\
\hline Other & 0.201 & 0.177 & 1.222 & 0.113 & 0.223 & 1.119 & 0.386 & 0.298 & 1.470 \\
\hline \multicolumn{10}{|l|}{ White (reference) } \\
\hline \multicolumn{10}{|c|}{ Academic and financial resources } \\
\hline Lowest quartile salary & 0.619 & 0.088 & $1.858 * * *$ & 0.623 & 0.118 & $1.865^{* * *}$ & 0.660 & 0.137 & $1.934 * * *$ \\
\hline 2nd quartile salary & 0.201 & 0.090 & $1.222 *$ & 0.219 & 0.125 & 1.245 & 0.149 & 0.136 & 1.161 \\
\hline 3rd quartile salary & -0.341 & 0.097 & $0.711 * * *$ & -0.288 & 0.137 & $0.750 *$ & -0.465 & 0.142 & $0.628 * *$ \\
\hline \multicolumn{10}{|l|}{ Top quartile salary (reference) } \\
\hline $\begin{array}{l}\text { Did not delay college } \\
\text { Delayed college (reference) }\end{array}$ & -0.030 & 0.095 & 0.970 & -0.048 & 0.128 & 0.953 & 0.033 & 0.146 & 1.034 \\
\hline Completed BA in 4 years & 0.030 & 0.109 & 1.031 & 0.168 & 0.144 & 1.183 & -0.210 & 0.174 & 0.810 \\
\hline Completed BA in 5 years & 0.141 & 0.101 & 1.151 & 0.196 & 0.140 & 1.217 & 0.066 & 0.151 & 1.068 \\
\hline Completed BA in 5-7 years & -0.026 & 0.102 & 0.975 & 0.140 & 0.143 & 1.150 & -0.178 & 0.149 & 0.837 \\
\hline \multicolumn{10}{|c|}{ Completed 7 years + (reference $)$} \\
\hline $\begin{array}{l}\text { Married in } 1993 \\
\text { Not married (reference) }\end{array}$ & -0.307 & 0.100 & $0.735^{* *}$ & -0.308 & 0.127 & $0.735^{*}$ & -0.367 & 0.170 & 0.693 \\
\hline No dependents in 1993 & -0.062 & 0.101 & 0.940 & -0.101 & 0.128 & 0.904 & -0.113 & 0.181 & 0.893 \\
\hline \multicolumn{10}{|l|}{ At least 1 dependent (reference) } \\
\hline Dependent, $<\$ 30,000$ & -0.213 & 0.174 & 0.808 & -0.176 & 0.225 & 0.838 & -0.187 & 0.284 & 0.829 \\
\hline
\end{tabular}


TABLE 4 (Continued)

\begin{tabular}{|c|c|c|c|c|c|c|c|c|c|}
\hline Characteristic & B & $\begin{array}{l}\text { Total } \\
\text { Std. } \\
\text { Error }\end{array}$ & $\begin{array}{l}\text { Odds- } \\
\text { ratio }\end{array}$ & B & $\begin{array}{l}\text { Women } \\
\text { Std. } \\
\text { Error }\end{array}$ & $\begin{array}{l}\text { Odds- } \\
\text { ratio }\end{array}$ & B & $\begin{array}{l}\text { Men } \\
\text { Std. } \\
\text { Error }\end{array}$ & $\begin{array}{l}\text { Odds- } \\
\text { ratio }\end{array}$ \\
\hline Dependent, $\$ 30 \mathrm{~K}-\$ 50 \mathrm{~K}$ & -0.121 & 0.167 & 0.886 & 0.093 & 0.216 & 1.098 & -0.433 & 0.276 & 0.648 \\
\hline Dependent, $\$ 50 \mathrm{~K}-\$ 70 \mathrm{~K}$ & -0.241 & 0.162 & 0.786 & -0.256 & 0.210 & 0.774 & -0.237 & 0.263 & 0.789 \\
\hline Dependent, $\$ 70 \mathrm{~K}+$ & -0.124 & 0.167 & 0.883 & -0.079 & 0.216 & 0.924 & -0.218 & 0.272 & 0.804 \\
\hline Independent, $<\$ 10,000$ & 0.009 & 0.139 & 1.009 & -0.080 & 0.182 & 0.923 & 0.045 & 0.228 & 1.046 \\
\hline Independent, $\$ 10 \mathrm{~K}-\$ 30 \mathrm{~K}$ & -0.257 & 0.126 & $0.773 *$ & -0.258 & 0.162 & 0.773 & -0.244 & 0.210 & 0.783 \\
\hline \multicolumn{10}{|l|}{ Independent, $\$ 30 K+($ reference $)$} \\
\hline Did not borrow & 0.306 & 0.094 & $1.357 * *$ & 0.272 & 0.125 & $1.313^{*}$ & 0.374 & 0.147 & $1.453^{*}$ \\
\hline Borrowed less than $\$ 4,000$ & 0.288 & 0.122 & $1.333 *$ & 0.392 & 0.160 & $1.480 *$ & 0.186 & 0.195 & 1.205 \\
\hline Borrowed $\$ 4,000-\$ 7,999$ & 0.093 & 0.119 & 1.098 & 0.177 & 0.159 & 1.194 & -0.001 & 0.186 & 0.999 \\
\hline Borrowed $\$ 8,000-\$ 12,599$ & 0.354 & 0.113 & $1.424 * *$ & 0.347 & 0.150 & $1.414^{*}$ & 0.343 & 0.179 & 1.409 \\
\hline \multicolumn{10}{|l|}{ Borrowed $\$ 12,600+($ reference $)$} \\
\hline Grades Bs \& Cs and below & 0.092 & 0.116 & 1.097 & 0.100 & 0.154 & 1.106 & 0.161 & 0.198 & 1.175 \\
\hline Grades mostly Bs & 0.250 & 0.100 & $1.285^{*}$ & 0.282 & 0.123 & $1.326^{*}$ & 0.292 & 0.183 & 1.339 \\
\hline Grades As \& Bs & 0.103 & 0.102 & 1.108 & 0.054 & 0.122 & 1.055 & 0.212 & 0.192 & 1.236 \\
\hline \multicolumn{10}{|l|}{ Grades mostly As (reference) } \\
\hline Did not take SAT/ACT & 0.187 & 0.115 & 1.206 & 0.327 & 0.158 & $1.387 *$ & 0.024 & 0.175 & 1.024 \\
\hline Lowest quartile SAT/ACT & -0.088 & 0.109 & 0.916 & -0.007 & 0.148 & 0.993 & -0.247 & 0.168 & 0.781 \\
\hline 2nd quartile SAT/ACT & -0.117 & 0.103 & 0.890 & -0.136 & 0.144 & 0.873 & -0.055 & 0.152 & 0.947 \\
\hline 3rd quartile SAT/ACT & 0.123 & 0.101 & 1.131 & 0.241 & 0.145 & 1.272 & -0.001 & 0.145 & 0.999 \\
\hline \multicolumn{10}{|l|}{ 4th quartile (reference) } \\
\hline \multicolumn{10}{|l|}{ Cultural \& social capital } \\
\hline Parents' no more than high school & -0.170 & 0.119 & 0.844 & -0.013 & 0.167 & 0.987 & -0.364 & 0.175 & $0.695^{*}$ \\
\hline Parents' some college & 0.064 & 0.117 & 1.066 & 0.092 & 0.165 & 1.096 & 0.043 & 0.171 & 1.044 \\
\hline Parents' bachelor's degree & -0.109 & 0.115 & 0.897 & 0.088 & 0.162 & 1.092 & -0.387 & 0.168 & $0.679 *$ \\
\hline Parents' master's degree & 0.110 & 0.121 & 1.116 & 0.289 & 0.170 & 1.335 & -0.160 & 0.179 & 0.852 \\
\hline
\end{tabular}


TABLE 4 (Continued)

\begin{tabular}{|c|c|c|c|c|c|c|c|c|c|}
\hline Characteristic & B & $\begin{array}{l}\text { Total } \\
\text { Std. } \\
\text { Error }\end{array}$ & $\begin{array}{l}\text { Odds- } \\
\text { ratio }\end{array}$ & B & $\begin{array}{l}\text { Women } \\
\text { Std. } \\
\text { Error }\end{array}$ & $\begin{array}{l}\text { Odds- } \\
\text { ratio }\end{array}$ & B & $\begin{array}{l}\text { Men } \\
\text { Std. } \\
\text { Error }\end{array}$ & $\begin{array}{l}\text { Odds- } \\
\text { ratio }\end{array}$ \\
\hline \multicolumn{10}{|c|}{ Parents'advanced degree (reference) } \\
\hline $\begin{array}{l}\text { English spoken at home } \\
\text { English not spoken (reference) }\end{array}$ & 0.365 & \multicolumn{3}{|c|}{ English not spoken (reference) } & 0.165 & $1.716^{* *}$ & 0.140 & 0.206 & 1.150 \\
\hline Important: job success & 0.013 & 0.033 & 1.013 & 0.043 & 0.047 & 1.044 & -0.027 & 0.050 & 0.973 \\
\hline Important: work life quality & 0.055 & 0.031 & 1.056 & 0.148 & 0.041 & $1.160 * * *$ & -0.057 & 0.050 & 0.944 \\
\hline Important: community leader & 0.230 & 0.067 & $1.258 * *$ & 0.335 & 0.089 & $1.398 * * *$ & 0.072 & 0.105 & 1.074 \\
\hline Important: authority in field & 0.051 & 0.074 & 1.052 & 0.062 & 0.096 & 1.064 & 0.047 & 0.122 & 1.048 \\
\hline Important: political structure & 0.044 & 0.066 & 1.045 & 0.076 & 0.089 & 1.079 & 0.040 & 0.102 & 1.041 \\
\hline Important: intellectual work & -0.075 & 0.080 & 0.928 & -0.247 & 0.107 & $0.781 *$ & 0.173 & 0.122 & 1.189 \\
\hline No direct parent support & 0.184 & 0.084 & $1.203^{*}$ & 0.037 & 0.111 & 1.038 & 0.398 & 0.134 & $1.488 * *$ \\
\hline Less than $\$ 1,500$ support & -0.032 & 0.110 & 0.969 & -0.337 & 0.150 & $0.714 *$ & 0.362 & 0.167 & $1.436^{*}$ \\
\hline$\$ 1,500-\$ 3,999$ support & 0.117 & 0.105 & 1.124 & -0.011 & 0.140 & 0.989 & 0.258 & 0.164 & 1.294 \\
\hline & \multicolumn{4}{|c|}{$\$ 8,000$ support (reference) } & 0.139 & 0.956 & 0.290 & 0.167 & 1.337 \\
\hline Research I university & 0.046 & 0.101 & 1.047 & 0.218 & 0.136 & 1.243 & -0.183 & 0.157 & 0.833 \\
\hline Other doctoral university & 0.064 & 0.098 & 1.066 & 0.307 & 0.127 & $1.359^{*}$ & -0.314 & 0.159 & $0.730^{*}$ \\
\hline Comprehensive I & 0.133 & 0.089 & 1.142 & 0.177 & 0.115 & 1.193 & 0.036 & 0.144 & 1.036 \\
\hline Liberal arts I & 0.330 & 0.167 & $1.390^{*}$ & 0.136 & 0.231 & 1.145 & 0.619 & 0.251 & $1.857 *$ \\
\hline \multicolumn{10}{|l|}{ Other institution (reference) } \\
\hline Lowest quartile tuition & 0.133 & 0.097 & 1.142 & 0.053 & 0.124 & 1.054 & 0.263 & 0.160 & 1.301 \\
\hline 2nd quartile tuition & 0.160 & 0.094 & 1.174 & 0.085 & 0.121 & 1.089 & 0.311 & 0.153 & $1.365^{*}$ \\
\hline 3rd quartile tuition & 0.164 & 0.090 & 1.179 & 0.046 & 0.117 & 1.047 & 0.273 & 0.146 & 1.313 \\
\hline \multicolumn{10}{|l|}{ Highest quartile (reference) } \\
\hline Attended same state & 0.258 & 0.096 & $1.294 * *$ & 0.181 & 0.125 & 1.198 & 0.360 & 0.157 & $1.434 *$ \\
\hline Attended same region & 0.426 & 0.127 & $1.532 * *$ & 0.176 & 0.176 & 1.192 & 0.708 & 0.193 & $2.030 * * *$ \\
\hline
\end{tabular}




\begin{tabular}{|c|c|c|c|c|c|c|c|c|c|}
\hline \multicolumn{10}{|l|}{ TABLE 4 (Continued) } \\
\hline Characteristic & B & $\begin{array}{l}\text { Total } \\
\text { Std. } \\
\text { Error }\end{array}$ & $\begin{array}{l}\text { Odds- } \\
\text { ratio }\end{array}$ & B & $\begin{array}{l}\text { Women } \\
\text { Std. } \\
\text { Error }\end{array}$ & $\begin{array}{l}\text { Odds- } \\
\text { ratio }\end{array}$ & B & $\begin{array}{l}\text { Men } \\
\text { Std. } \\
\text { Error }\end{array}$ & $\begin{array}{l}\text { Odds- } \\
\text { ratio }\end{array}$ \\
\hline \multicolumn{10}{|c|}{ Attended out of region (reference) } \\
\hline $\begin{array}{l}\text { Attended 2-year institution } \\
\text { Did not attend 2-year (refere }\end{array}$ & 0.223 & 0.066 & $1.250 * *$ & 0.287 & 0.088 & $1.333^{* *}$ & 0.151 & 0.104 & 1.163 \\
\hline Number items missing & 0.096 & 0.020 & $1.101 * * *$ & 0.140 & 0.026 & $1.150 * * *$ & 0.031 & 0.033 & 1.031 \\
\hline Intercept & -2.714 & 0.308 & $* * *$ & -2.856 & 0.400 & $* * *$ & -2.283 & 0.502 & $* * *$ \\
\hline Number cases & 8,969 & & & 4,934 & & & 4,026 & & \\
\hline$-2 \log$ likelihood, df & 19,084 & $171 * * *$ & & 10,509 & $168 * * *$ & & 8,292 & $168 * * *$ & \\
\hline Model fi-Pearson _ ${ }_{-}^{2}$ & 27,312 & $26,607 * *$ & & 15,154 & 16,153 & & 12,265 & $11,286^{* * *}$ & \\
\hline Pseudo R² (McFadden) & 0.09 & & & 0.082 & & & 0.108 & & \\
\hline \multicolumn{10}{|l|}{$\%$ correctly classified } \\
\hline Total & $55 \%$ & & & $53 \%$ & & & $59 \%$ & & \\
\hline Enrolled sub-master & $2 \%$ & & & $4 \%$ & & & $7 \%$ & & \\
\hline
\end{tabular}

NOTES: Enrollment is relative to no enrollment by 1997. *** $\mathrm{p}<.001, \quad * * \mathrm{p}<.01, \quad * \mathrm{p}<.05$ SOuRCE: Analyses of B\&B:93/97 
TABLE 5

Predictors of Highest Enrollment by 1997 For Male and Female 1992/93 Bachelor's Degree Recipients Using Multinomial Logistic Regression: Master's Degree Enrollment

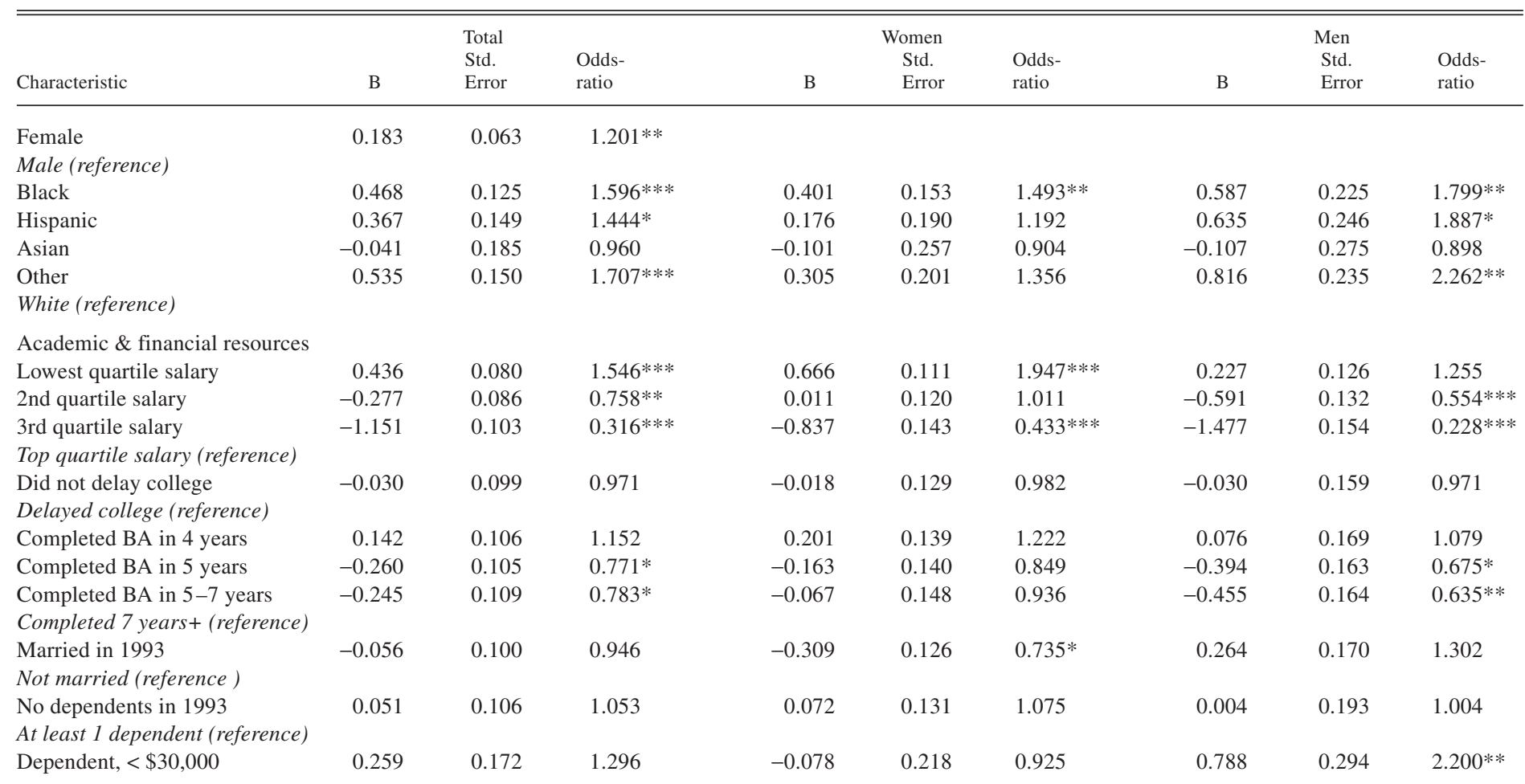


TABLE 5 (Continued)

\begin{tabular}{|c|c|c|c|c|c|c|c|c|c|}
\hline Characteristic & B & $\begin{array}{l}\text { Total } \\
\text { Std. } \\
\text { Error }\end{array}$ & $\begin{array}{l}\text { Odds- } \\
\text { ratio }\end{array}$ & B & $\begin{array}{l}\text { Women } \\
\text { Std. } \\
\text { Error }\end{array}$ & $\begin{array}{l}\text { Odds- } \\
\text { ratio }\end{array}$ & B & $\begin{array}{l}\text { Men } \\
\text { Std. } \\
\text { Error }\end{array}$ & $\begin{array}{l}\text { Odds- } \\
\text { ratio }\end{array}$ \\
\hline Dependent, $\$ 30 \mathrm{~K}-\$ 50 \mathrm{~K}$ & 0.379 & 0.164 & $1.461 *$ & 0.114 & 0.210 & 1.120 & 0.783 & 0.280 & $2.187 * *$ \\
\hline Dependent, $\$ 50 \mathrm{~K}-\$ 70 \mathrm{~K}$ & 0.334 & 0.158 & $1.396^{*}$ & -0.095 & 0.202 & 0.909 & 0.959 & 0.268 & $2.609 * * *$ \\
\hline Dependent, $\$ 70 \mathrm{~K}+$ & 0.504 & 0.162 & $1.656^{* *}$ & 0.253 & 0.205 & 1.288 & 0.884 & 0.276 & $2.420 * *$ \\
\hline Independent, $<\$ 10,000$ & 0.082 & 0.142 & 1.085 & -0.256 & 0.181 & 0.774 & 0.592 & 0.241 & $1.808^{*}$ \\
\hline Independent, $\$ 10 \mathrm{~K}-\$ 30 \mathrm{~K}$ & -0.212 & 0.129 & 0.809 & -0.458 & 0.163 & $0.632 * *$ & 0.195 & 0.221 & 1.215 \\
\hline \multicolumn{10}{|l|}{ Independent, $\$ 30 K+($ reference $)$} \\
\hline Did not borrow & 0.148 & 0.090 & 1.160 & 0.138 & 0.119 & 1.148 & 0.192 & 0.142 & 1.211 \\
\hline Borrowed less than $\$ 4,000$ & 0.211 & 0.120 & 1.234 & 0.261 & 0.156 & 1.298 & 0.199 & 0.193 & 1.220 \\
\hline Borrowed $\$ 4,000-\$ 7,999$ & 0.227 & 0.113 & $1.254 *$ & 0.360 & 0.148 & $1.433 *$ & 0.068 & 0.181 & 1.071 \\
\hline Borrowed $\$ 8,000-\$ 12,599$ & 0.128 & 0.115 & 1.137 & 0.134 & 0.149 & 1.143 & 0.164 & 0.184 & 1.179 \\
\hline \multicolumn{10}{|l|}{ Borrowed $\$ 12,600+($ reference $)$} \\
\hline Grades Bs \& Cs and below & -0.795 & 0.118 & $0.452 * * *$ & -0.677 & 0.158 & $0.508 * * *$ & -0.969 & 0.189 & $0.379 * * *$ \\
\hline Grades mostly Bs & -0.301 & 0.091 & $0.740 * *$ & -0.243 & 0.114 & $0.784 *$ & -0.382 & 0.158 & $0.682 *$ \\
\hline Grades As \& Bs & -0.074 & 0.090 & 0.929 & -0.088 & 0.109 & 0.916 & -0.080 & 0.162 & 0.924 \\
\hline \multicolumn{10}{|l|}{ Grades mostly As (reference) } \\
\hline Did not take SAT/ACT & -0.011 & 0.114 & 0.989 & 0.082 & 0.152 & 1.086 & -0.058 & 0.180 & 0.944 \\
\hline Lowest quartile SAT/ACT & -0.165 & 0.106 & 0.848 & -0.112 & 0.141 & 0.894 & -0.240 & 0.173 & 0.787 \\
\hline 2nd quartile SAT/ACT & -0.147 & 0.098 & 0.863 & -0.106 & 0.132 & 0.899 & -0.180 & 0.153 & 0.835 \\
\hline 3rd quartile SAT/ACT & 0.007 & 0.095 & 1.008 & 0.102 & 0.134 & 1.107 & -0.022 & 0.138 & 0.978 \\
\hline \multicolumn{10}{|l|}{ 4th quartile (reference) } \\
\hline \multicolumn{10}{|l|}{ Cultural \& social capital } \\
\hline Parents' no more than high school & -0.440 & 0.112 & $0.644 * * *$ & -0.582 & 0.147 & $0.559 * * *$ & -0.192 & 0.179 & 0.825 \\
\hline Parents' some college & -0.315 & 0.111 & $0.730 * *$ & -0.532 & 0.146 & $0.588 * * *$ & 0.048 & 0.178 & 1.049 \\
\hline Parents' bachelor's degree & -0.452 & 0.106 & $0.636 * * *$ & -0.567 & 0.141 & $0.567 * * *$ & -0.261 & 0.169 & 0.770 \\
\hline Parents' master's degree & -0.150 & 0.111 & 0.861 & -0.281 & 0.148 & 0.755 & 0.063 & 0.175 & 1.065 \\
\hline
\end{tabular}


TABLE 5 (Continued)

\begin{tabular}{|c|c|c|c|c|c|c|c|c|c|}
\hline Characteristic & B & $\begin{array}{l}\text { Total } \\
\text { Std. } \\
\text { Error }\end{array}$ & $\begin{array}{l}\text { Odds- } \\
\text { ratio }\end{array}$ & B & $\begin{array}{l}\text { Women } \\
\text { Std. } \\
\text { Error }\end{array}$ & $\begin{array}{l}\text { Odds- } \\
\text { ratio }\end{array}$ & B & $\begin{array}{l}\text { Men } \\
\text { Std. } \\
\text { Error }\end{array}$ & $\begin{array}{l}\text { Odds- } \\
\text { ratio }\end{array}$ \\
\hline \multicolumn{10}{|c|}{ Parents' advanced degree (reference) } \\
\hline $\begin{array}{l}\text { English spoken at home } \\
\text { English not spoken (reference) }\end{array}$ & 0.343 & 0.122 & $1.409 * *$ & 0.468 & 0.158 & $1.597 * *$ & 0.079 & 0.197 & 1.082 \\
\hline Important: job success & -0.050 & 0.031 & 0.951 & -0.043 & 0.041 & 0.958 & -0.056 & 0.051 & 0.946 \\
\hline Important: work life quality & 0.023 & 0.032 & 1.023 & 0.071 & 0.042 & 1.073 & -0.033 & 0.053 & 0.968 \\
\hline Important: community leader & 0.111 & 0.068 & 1.117 & 0.166 & 0.087 & 1.180 & 0.076 & 0.113 & 1.078 \\
\hline Important: authority in field & 0.074 & 0.076 & 1.077 & 0.057 & 0.095 & 1.059 & 0.145 & 0.130 & 1.156 \\
\hline Important: political structure & 0.275 & 0.067 & $1.317 * * *$ & 0.291 & 0.087 & $1.337 * *$ & 0.272 & 0.108 & $1.312 *$ \\
\hline Important: intellectual work & 0.115 & 0.078 & 1.122 & 0.069 & 0.100 & 1.071 & 0.174 & 0.128 & 1.189 \\
\hline No direct parent support & 0.240 & 0.083 & $1.271 * *$ & 0.190 & 0.109 & 1.209 & 0.337 & 0.133 & $1.401 *$ \\
\hline Less than $\$ 1,500$ support & 0.015 & 0.110 & 1.016 & -0.037 & 0.142 & 0.964 & 0.089 & 0.180 & 1.093 \\
\hline$\$ 1,500-\$ 3,999$ support & 0.145 & 0.104 & 1.157 & 0.151 & 0.136 & 1.163 & 0.126 & 0.167 & 1.134 \\
\hline \multicolumn{10}{|l|}{$\$ 8,000$ support (reference) } \\
\hline Research I university & 0.316 & 0.101 & $1.372 * *$ & 0.302 & 0.132 & $1.352 *$ & 0.318 & 0.162 & $1.374 *$ \\
\hline Other doctoral university & 0.244 & 0.098 & $1.276^{*}$ & 0.331 & 0.125 & $1.392 * *$ & 0.116 & 0.165 & 1.123 \\
\hline Comprehensive I & 0.246 & 0.090 & $1.279 * *$ & 0.214 & 0.113 & 1.239 & 0.293 & 0.155 & 1.341 \\
\hline Liberal arts I & 0.238 & 0.156 & 1.269 & 0.282 & 0.204 & 1.326 & 0.226 & 0.252 & 1.253 \\
\hline \multicolumn{10}{|l|}{ Other institution (reference) } \\
\hline Lowest quartile tuition & -0.097 & 0.093 & 0.907 & 0.012 & 0.119 & 1.012 & -0.277 & 0.154 & 0.758 \\
\hline 2nd quartile tuition & -0.208 & 0.091 & $0.812 *$ & -0.079 & 0.118 & 0.924 & -0.438 & 0.149 & $0.645^{* *}$ \\
\hline 3rd quartile tuition & -0.028 & 0.086 & 0.972 & -0.096 & 0.113 & 0.909 & 0.058 & 0.137 & 1.060 \\
\hline \multicolumn{10}{|l|}{ Highest quartile (reference) } \\
\hline Attended same state & 0.237 & 0.089 & $1.268 * *$ & 0.229 & 0.119 & 1.258 & 0.325 & 0.139 & $1.385^{*}$ \\
\hline Attended same region & 0.159 & 0.124 & 1.173 & 0.229 & 0.165 & 1.257 & 0.140 & 0.196 & 1.150 \\
\hline
\end{tabular}




\begin{tabular}{|c|c|c|c|c|c|c|c|c|c|}
\hline \multicolumn{10}{|l|}{ TABLE 5 (Continued) } \\
\hline Characteristic & B & $\begin{array}{l}\text { Total } \\
\text { Std. } \\
\text { Error }\end{array}$ & $\begin{array}{l}\text { Odds- } \\
\text { ratio }\end{array}$ & B & $\begin{array}{l}\text { Women } \\
\text { Std. } \\
\text { Error }\end{array}$ & $\begin{array}{l}\text { Odds- } \\
\text { ratio }\end{array}$ & B & $\begin{array}{l}\text { Men } \\
\text { Std. } \\
\text { Error }\end{array}$ & $\begin{array}{l}\text { Odds- } \\
\text { ratio }\end{array}$ \\
\hline \multicolumn{10}{|c|}{ Attended out of region (reference) } \\
\hline $\begin{array}{l}\text { Attended 2-year institution } \\
\text { Did not attend 2-year (refere }\end{array}$ & 0.191 & 0.068 & $1.211^{* *}$ & 0.280 & 0.087 & $1.323^{* *}$ & 0.060 & 0.113 & 1.062 \\
\hline Number items missing & 0.179 & 0.019 & $1.196^{* * *}$ & 0.185 & 0.024 & $1.203 * * *$ & 0.192 & 0.031 & $1.211 * * *$ \\
\hline Intercept & -1.899 & 0.298 & $* * *$ & -1.810 & 0.379 & $* * *$ & -2.043 & 0.497 & $* * *$ \\
\hline Number cases & 8,969 & & & 4,934 & & & 4,026 & & \\
\hline$-2 \log$ likelihood, df & 19,084 & $171 * * *$ & & 10,509 & $168 * * *$ & & 8,292 & $168 * * *$ & \\
\hline Model fit-Pearson $\chi^{2}$ & 27,312 & $26,607 * *$ & & 15,154 & 16,153 & & 12,265 & $11,286 * * *$ & \\
\hline Pseudo R² (McFadden) & 0.09 & & & 0.082 & & & 0.108 & & \\
\hline \multicolumn{10}{|l|}{$\%$ correctly classified } \\
\hline Total & $55 \%$ & & & $53 \%$ & & & $59 \%$ & & \\
\hline Enrolled master's degree & $19 \%$ & & & $23 \%$ & & & $18 \%$ & & \\
\hline
\end{tabular}

NOTES: Enrollment is relative to no enrollment by 1997. $* * * \mathrm{p}<.001, \quad * * \mathrm{p}<.01, \quad * \mathrm{p}<.05$

SOURCE: Analyses of B\&B:93/97 
TABLE 6

Predictors of Highest Enrollment by 1997 For Male and Female 1992/93 Bachelor's Degree Recipients Using Multinomial Logistic Regression: First-Professional Enrollment

\begin{tabular}{|c|c|c|c|c|c|c|c|c|c|}
\hline Characteristic & B & $\begin{array}{l}\text { Total } \\
\text { Std. } \\
\text { Error }\end{array}$ & $\begin{array}{l}\text { Odds- } \\
\text { ratio }\end{array}$ & B & $\begin{array}{l}\text { Women } \\
\text { Std. } \\
\text { Error }\end{array}$ & $\begin{array}{l}\text { Odds- } \\
\text { ratio }\end{array}$ & $\mathrm{B}$ & $\begin{array}{l}\text { Men } \\
\text { Std. } \\
\text { Error }\end{array}$ & $\begin{array}{l}\text { Odds- } \\
\text { ratio }\end{array}$ \\
\hline Female & -0.690 & 0.095 & $0.501 * * *$ & & & & & & \\
\hline \multicolumn{10}{|l|}{ Male (reference) } \\
\hline Black & 0.901 & 0.203 & $2.462 * * *$ & 1.375 & 0.263 & $3.953 * * *$ & 0.152 & 0.370 & 1.164 \\
\hline Hispanic & 0.765 & 0.220 & $2.150 * *$ & 0.444 & 0.337 & 1.558 & 1.071 & 0.304 & $2.919 * * *$ \\
\hline Asian & 0.873 & 0.201 & $2.393 * * *$ & 0.537 & 0.344 & 1.711 & 1.029 & 0.259 & $2.800 * * *$ \\
\hline Other & 0.481 & 0.223 & $1.617 *$ & 0.568 & 0.318 & 1.764 & 0.371 & 0.325 & 1.450 \\
\hline \multicolumn{10}{|l|}{ White (reference) } \\
\hline \multicolumn{10}{|c|}{ Academic \& financial resources } \\
\hline Lowest quartile salary & 0.530 & 0.141 & $1.699 * * *$ & 0.275 & 0.225 & 1.316 & 0.671 & 0.184 & $1.957 * * *$ \\
\hline 2nd quartile salary & 0.466 & 0.139 & $1.593 * *$ & 0.359 & 0.224 & 1.432 & 0.469 & 0.181 & $1.599 * *$ \\
\hline 3rd quartile salary & 0.195 & 0.146 & 1.215 & 0.063 & 0.248 & 1.065 & 0.194 & 0.185 & 1.215 \\
\hline \multicolumn{10}{|c|}{ Highest quartile salary (reference) } \\
\hline Did not delay college & -0.148 & 0.172 & 0.862 & -0.458 & 0.270 & 0.633 & 0.118 & 0.231 & 1.125 \\
\hline \multicolumn{10}{|l|}{ Delayed college (reference) } \\
\hline Completed BA in 4 years & 0.564 & 0.168 & $1.757 * *$ & 0.409 & 0.270 & 1.506 & 0.631 & 0.221 & $1.880 * *$ \\
\hline Completed BA in 5 years & -0.098 & 0.175 & 0.906 & 0.068 & 0.277 & 1.070 & -0.264 & 0.231 & 0.768 \\
\hline Completed BA in 5-7 years & 0.040 & 0.184 & 1.041 & -0.146 & 0.342 & 0.864 & 0.093 & 0.227 & 1.097 \\
\hline \multicolumn{10}{|c|}{ Completed 7 years $+($ reference $)$} \\
\hline Married in 1993 & -0.195 & 0.178 & 0.823 & -0.352 & 0.289 & 0.703 & -0.026 & 0.236 & 0.974 \\
\hline \multicolumn{10}{|l|}{ Not married (reference) } \\
\hline No dependents in 1993 & -0.188 & 0.200 & 0.829 & -0.478 & 0.321 & 0.620 & -0.019 & 0.274 & 0.981 \\
\hline \multicolumn{10}{|c|}{ At least 1 dependent (reference) } \\
\hline Dependent, $<\$ 30,000$ & 0.479 & 0.275 & 1.615 & 1.097 & 0.443 & $2.995 *$ & 0.170 & 0.369 & 1.185 \\
\hline
\end{tabular}


TABLE 6 (Continued)

\begin{tabular}{|c|c|c|c|c|c|c|c|c|c|}
\hline Characteristic & B & $\begin{array}{l}\text { Total } \\
\text { Std. } \\
\text { Error }\end{array}$ & $\begin{array}{l}\text { Odds- } \\
\text { ratio }\end{array}$ & B & $\begin{array}{l}\text { Women } \\
\text { Std. } \\
\text { Error }\end{array}$ & $\begin{array}{l}\text { Odds- } \\
\text { ratio }\end{array}$ & B & $\begin{array}{l}\text { Men } \\
\text { Std. } \\
\text { Error }\end{array}$ & $\begin{array}{l}\text { Odds- } \\
\text { ratio }\end{array}$ \\
\hline Dependent, $\$ 30 \mathrm{~K}-\$ 50 \mathrm{~K}$ & 0.416 & 0.267 & 1.515 & 0.909 & 0.431 & $2.481 *$ & 0.192 & 0.357 & 1.212 \\
\hline Dependent, $\$ 50 \mathrm{~K}-\$ 70 \mathrm{~K}$ & 0.394 & 0.252 & 1.484 & 0.787 & 0.409 & 2.197 & 0.280 & 0.333 & 1.324 \\
\hline Dependent, $\$ 70 \mathrm{~K}+$ & 0.679 & 0.257 & $1.972 * *$ & 1.169 & 0.413 & $3.219 * *$ & 0.462 & 0.343 & 1.587 \\
\hline Independent, $<\$ 10,000$ & -0.069 & 0.247 & 0.933 & 0.113 & 0.415 & 1.120 & -0.101 & 0.320 & 0.904 \\
\hline Independent, $\$ 10 \mathrm{~K}-\$ 30 \mathrm{~K}$ & -0.236 & 0.233 & 0.790 & -0.163 & 0.401 & 0.849 & -0.277 & 0.298 & 0.758 \\
\hline \multicolumn{10}{|l|}{ Independent, $\$ 30 K+($ reference $)$} \\
\hline Did not borrow & 0.073 & 0.138 & 1.075 & 0.197 & 0.227 & 1.217 & 0.041 & 0.179 & 1.042 \\
\hline Borrowed less than $\$ 4,000$ & 0.053 & 0.191 & 1.054 & 0.378 & 0.297 & 1.460 & -0.176 & 0.258 & 0.838 \\
\hline Borrowed $\$ 4,000-\$ 7,999$ & 0.090 & 0.180 & 1.094 & 0.646 & 0.268 & $1.908^{*}$ & -0.380 & 0.254 & 0.684 \\
\hline Borrowed $\$ 8,000-\$ 12,599$ & 0.067 & 0.182 & 1.069 & 0.084 & 0.299 & 1.087 & 0.049 & 0.238 & 1.050 \\
\hline \multicolumn{10}{|l|}{ Borrowed $\$ 12,600+($ reference $)$} \\
\hline Grades Bs \& Cs and below & -1.444 & 0.196 & $0.236^{* * *}$ & -1.061 & 0.330 & $0.346^{* *}$ & -1.676 & 0.252 & $0.187 * * *$ \\
\hline Grades mostly Bs & -0.675 & 0.134 & $0.509 * * *$ & -0.413 & 0.211 & 0.661 & -0.856 & 0.182 & $0.425 * * *$ \\
\hline Grades As \& Bs & -0.153 & 0.128 & 0.858 & 0.083 & 0.196 & 1.087 & -0.280 & 0.180 & 0.756 \\
\hline \multicolumn{10}{|l|}{ Grades mostly As (reference) } \\
\hline Did not take SAT/ACT & -1.080 & 0.188 & $0.340 * * *$ & -1.157 & 0.301 & $0.314 * * *$ & -1.010 & 0.247 & $0.364 * * *$ \\
\hline Lowest quartile SAT/ACT & -1.296 & 0.182 & $0.274 * * *$ & -1.356 & 0.266 & $0.258 * * *$ & -1.251 & 0.256 & $0.286^{* * *}$ \\
\hline 2nd quartile SAT/ACT & -0.651 & 0.136 & $0.521 * * *$ & -1.067 & 0.224 & $0.344 * * *$ & -0.389 & 0.176 & $0.678^{*}$ \\
\hline 3rd quartile SAT/ACT & -0.336 & 0.121 & $0.715^{* *}$ & -0.170 & 0.194 & 0.843 & -0.389 & 0.159 & $0.678^{*}$ \\
\hline \multicolumn{10}{|l|}{ 4th quartile (reference) } \\
\hline \multicolumn{10}{|l|}{ Cultural \& social capital } \\
\hline Parents' no more than high school & -0.626 & 0.164 & $0.535 * * *$ & -0.668 & 0.266 & $0.512^{*}$ & -0.604 & 0.216 & $0.547 * *$ \\
\hline Parents' some college & -0.467 & 0.160 & $0.627 * *$ & -0.582 & 0.260 & $0.559^{*}$ & -0.404 & 0.209 & 0.668 \\
\hline Parents' bachelor's degree & -0.603 & 0.146 & $0.547 * * *$ & -0.739 & 0.242 & $0.478 * *$ & -0.578 & 0.189 & $0.561 * *$ \\
\hline Parents' master's degree & -0.225 & 0.149 & 0.799 & -0.201 & 0.240 & 0.818 & -0.272 & 0.196 & 0.762 \\
\hline
\end{tabular}


TABLE 6 (Continued)

\begin{tabular}{|c|c|c|c|c|c|c|c|c|c|}
\hline Characteristic & B & $\begin{array}{l}\text { Total } \\
\text { Std. } \\
\text { Error }\end{array}$ & $\begin{array}{l}\text { Odds- } \\
\text { ratio }\end{array}$ & B & $\begin{array}{l}\text { Women } \\
\text { Std. } \\
\text { Error }\end{array}$ & $\begin{array}{l}\text { Odds- } \\
\text { ratio }\end{array}$ & B & $\begin{array}{l}\text { Men } \\
\text { Std. } \\
\text { Error }\end{array}$ & $\begin{array}{l}\text { Odds- } \\
\text { ratio }\end{array}$ \\
\hline \multicolumn{10}{|c|}{ Parents'advanced degree (reference) } \\
\hline $\begin{array}{l}\text { English spoken at home } \\
\text { English not spoken (reference) }\end{array}$ & 0.056 & 0.167 & 1.057 & 0.068 & 0.246 & 1.070 & 0.051 & 0.236 & 1.052 \\
\hline Important: job success & -0.029 & 0.053 & 0.971 & -0.094 & 0.083 & 0.910 & 0.023 & 0.071 & 1.024 \\
\hline Important: work life quality & -0.002 & 0.053 & 0.998 & -0.126 & 0.100 & 0.882 & 0.038 & 0.064 & 1.038 \\
\hline Important: community leader & 0.148 & 0.111 & 1.159 & 0.184 & 0.176 & 1.202 & 0.141 & 0.146 & 1.151 \\
\hline Important: authority in field & -0.015 & 0.119 & 0.985 & 0.358 & 0.197 & 1.431 & -0.259 & 0.155 & 0.772 \\
\hline Important: political structure & 0.220 & 0.107 & $1.246^{*}$ & 0.371 & 0.172 & $1.449 *$ & 0.093 & 0.141 & 1.097 \\
\hline Important: intellectual work & 0.066 & 0.122 & 1.068 & -0.015 & 0.197 & 0.985 & 0.105 & 0.161 & 1.110 \\
\hline No direct parent support & 0.333 & 0.131 & $1.395^{*}$ & 0.229 & 0.213 & 1.257 & 0.442 & 0.172 & $1.556^{*}$ \\
\hline Less than $\$ 1,500$ support & 0.093 & 0.175 & 1.098 & 0.063 & 0.268 & 1.065 & 0.108 & 0.237 & 1.114 \\
\hline$\$ 1,500-\$ 3,999$ support & 0.314 & 0.149 & $1.369^{*}$ & 0.472 & 0.232 & $1.603 *$ & 0.188 & 0.200 & 1.206 \\
\hline \multicolumn{10}{|l|}{$\$ 8,000$ support (reference) } \\
\hline Research I university & 0.932 & 0.171 & $2.540 * * *$ & 1.397 & 0.271 & $4.044 * * *$ & 0.693 & 0.226 & $2.000 * *$ \\
\hline Other doctoral university & 0.648 & 0.173 & $1.912 * * *$ & 0.914 & 0.277 & $2.495^{* *}$ & 0.517 & 0.230 & $1.676^{*}$ \\
\hline Comprehensive I & 0.516 & 0.168 & $1.676^{* *}$ & 0.561 & 0.270 & $1.752 *$ & 0.507 & 0.222 & $1.660^{*}$ \\
\hline Liberal arts I & 0.851 & 0.226 & $2.342 * * *$ & 1.235 & 0.355 & $3.437 * *$ & 0.646 & 0.300 & $1.908^{*}$ \\
\hline \multicolumn{10}{|l|}{ Other institution (reference) } \\
\hline Lowest quartile tuition & -0.120 & 0.150 & 0.887 & -0.182 & 0.233 & 0.834 & -0.072 & 0.202 & 0.930 \\
\hline 2nd quartile tuition & -0.158 & 0.143 & 0.854 & -0.316 & 0.229 & 0.729 & -0.083 & 0.188 & 0.920 \\
\hline 3rd quartile tuition & 0.230 & 0.128 & 1.259 & 0.127 & 0.202 & 1.135 & 0.259 & 0.171 & 1.295 \\
\hline \multicolumn{10}{|l|}{ Highest quartile (reference) } \\
\hline Attended same state & 0.254 & 0.128 & $1.289 *$ & 0.608 & 0.210 & $1.837 * *$ & 0.074 & 0.168 & 1.077 \\
\hline Attended same region & 0.335 & 0.169 & $1.398 *$ & 0.361 & 0.293 & 1.434 & 0.342 & 0.214 & 1.408 \\
\hline
\end{tabular}




\begin{tabular}{|c|c|c|c|c|c|c|c|c|c|}
\hline \multicolumn{10}{|l|}{ TABLE 6 (Continued) } \\
\hline Characteristic & B & $\begin{array}{l}\text { Total } \\
\text { Std. } \\
\text { Error }\end{array}$ & $\begin{array}{l}\text { Odds- } \\
\text { ratio }\end{array}$ & B & $\begin{array}{l}\text { Women } \\
\text { Std. } \\
\text { Error }\end{array}$ & $\begin{array}{l}\text { Odds- } \\
\text { ratio }\end{array}$ & B & $\begin{array}{l}\text { Men } \\
\text { Std. } \\
\text { Error }\end{array}$ & $\begin{array}{l}\text { Odds- } \\
\text { ratio }\end{array}$ \\
\hline \multicolumn{10}{|l|}{ Attended out of region (reference) } \\
\hline $\begin{array}{l}\text { Attended 2-year institution } \\
\text { Did not attend 2-year (reference, }\end{array}$ & 0.324 & 0.109 & $1.383 * *$ & 0.327 & 0.176 & 1.386 & 0.258 & 0.144 & 1.294 \\
\hline Number items missing & 0.257 & 0.027 & $1.293 * * *$ & 0.365 & 0.044 & $1.441 * * *$ & 0.189 & 0.037 & $1.208 * * *$ \\
\hline Intercept & -2.534 & 0.468 & $* * *$ & -3.997 & 0.754 & $* * *$ & -2.179 & 0.625 & $* * *$ \\
\hline Number cases & 8,969 & & & 4,934 & & & 4,026 & & \\
\hline$-2 \log$ likelihood & 19,084 & $171 * * *$ & & 10,509 & $168 * * *$ & & 8,292 & $168 * * *$ & \\
\hline Model fit-Pearson $\chi^{2}$ & 27,312 & $26,607 * *$ & & 15,154 & 16,153 & & 12,265 & $11,286 * * *$ & \\
\hline Pseudo R² (McFadden) & 0.09 & & & 0.082 & & & 0.108 & & \\
\hline \multicolumn{10}{|l|}{$\%$ correctly classified } \\
\hline Total & $55 \%$ & & & $53 \%$ & & & $59 \%$ & & \\
\hline Enrolled professional degree & $12 \%$ & & & $11 \%$ & & & $19 \%$ & & \\
\hline
\end{tabular}

NOTES: Enrollment is relative to no enrollment by 1997. *** $\mathrm{p}<.001, * * \mathrm{p}<.01, * \mathrm{p}<.05$

SOURCE: Analyses of B\&B:93/97 
A review of the multinomial logit analyses in the context of additional descriptive analyses suggests that sex differences in the distribution of women and men by starting salary of the undergraduate major field is one source of the observed overrepresentation of women among submaster's and master's program enrollees. Table 4 shows that, after controlling for other variables, the odds of enrolling in a submaster's level program are higher for both women and men bachelor's degree recipients with majors in the lowest quartile of starting salary (e.g., education, history, and psychology) than for bachelor's degree recipients with majors in the highest quartile of starting salary (e.g., math and other sciences, health professions, and engineering). As supported by the interaction between sex and starting salaries, Table 5 indicates that women with undergraduate major fields in the lowest quartile of starting salaries are more likely than women with undergraduate major fields in the highest quartile to enroll in a master's degree program by 1997 net of other variables, but that men with undergraduate major fields in the lowest quartile are as likely as men with undergraduate major fields in the highest quartile to enroll in a master's degree program. Descriptive analyses suggest that these relationships contribute to the observed overrepresentation of women in submaster's and master's level programs, as a higher share of women than men had undergraduate majors in the lowest quartile of starting salaries (38\% versus $24 \%$ ) and a smaller share of women than men had undergraduate majors in the highest quartile of starting salaries (16\% versus $23 \%)$.

The observed overrepresentation of women among master's degree program enrollments also appears to be attributable to sex differences in the distribution of bachelor's degree recipients by undergraduate cumulative grade-point average. Table 5 shows that the odds of enrolling in a master's degree program are lower for individuals with cumulative undergraduate grade-point averages that are no higher than Bs and Cs than for their counterparts with higher grades (odds ratio $=0.45$ ). This relationship appears to promote master's degree enrollment for a higher percentage of women than men, since women tend to have higher cumulative undergraduate grade-point averages than men. Descriptive analyses reveal that $20 \%$ of men, but only $13 \%$ of women, reported cumulative undergraduate grade-point averages of B's and C's or below.

Although the variables in the model do not explain the observed underrepresentation of women among first-professional enrollees, a review of the multinomial logit analyses in the context of additional descriptive analyses suggests three potential sources of the observed sex difference in enrollment. First, unlike for submaster's and master's degree enrollment, having an undergraduate major field in the lowest quartile of start- 
ing salaries, and thus the lowest opportunity costs of enrollment, does not promote the enrollment of women in first-professional degree programs. Table 6 shows that, while the odds of enrolling in a first-professional program are higher for men with undergraduate major fields in the lowest quartile of starting salary than for other men, the starting salary of the undergraduate major field is unrelated to the likelihood of enrolling in a first-professional program relative to not enrolling for women.

Second, both women and men bachelor's degree recipients who do not take the SAT/ACT or who have scores in the lowest quartile of the distribution are less likely than their counterparts who have scores in the upper two quartiles to have enrolled in a first-professional degree program by 1997. This relationship appears to promote the enrollment into first-professional degree programs of a smaller share of women than men. Descriptive analyses show that higher shares of women than men did not take the SAT or ACT (24\% versus 17\%) and scored in the lowest quartile of the distribution (21\% versus $16 \%$ ).

Third, as mentioned above, a statistically significant interaction suggests that the effect of Carnegie classification on post-baccalaureate enrollment is different for women than for men. Although the Carnegie classification of the undergraduate institution appears to be unrelated to the odds of enrolling in a sub-master's or master's level program among both women and men, Carnegie classification is related to the enrollment of women in a first-professional program. Even after controlling for measures of expected costs and benefits, financial and academic resources, and other measures of cultural and social capital, Table 6 shows that the odds of enrolling in a first-professional degree program relative to not enrolling are higher for women whose undergraduate institution was a research I university than for other women (odds ratio $=4.0$ ). For men, Carnegie classification is unrelated to the likelihood of enrolling in a first-professional program net of other variables. Nonetheless, although the professional degree enrollment "premium" that is associated with attending a research I university is greater for women than for men, a smaller share of women than men attended a research I university (20\% versus $27 \%)$.

\section{Racial/Ethnic Group Differences in Post-Baccalaureate Enrollment}

Descriptive analyses suggest that, although small in magnitude, the observed pattern of post-baccalaureate enrollment varies across racial/ethnic groups. Table 1 suggests that a higher share of Asians $(16 \%)$ than of all bachelor's degree recipients (7\%) enrolled in a first- 
professional degree program by 1997 . The multinomial logistic regression analyses show that this observed difference is not explained by the variables that are included in the model. Table 2 shows that the likelihood of enrolling in a first-professional program relative to not enrolling are higher for Asians than for Whites even after taking into account differences in expected costs and benefits, financial and academic resources, and cultural and social capital (odds ratio $=2.4$ ).

Descriptive analyses suggest that comparable shares of Blacks and Whites enroll in less-than-master's, master's, and first-professional degree programs (see Table 1). But, the multinomial logit analyses (Table 2) suggest that, when differences in expected costs and benefits, financial and academic resources, and cultural and social capital are taken into account, the likelihood of enrolling in either a master's or a professional degree program relative to not enrolling is higher for Blacks than for Whites (odds ratios of 1.6 and 2.5, respectively). A statistically significant interaction suggests that the relationship between being Black and post-baccalaureate enrollment is different for women and men. Separate analyses for women and men suggest that the odds of enrolling in a master's degree program are higher for both Black women (odds ratio $=1.5$ ) and Black men (odds ratio $=1.8$ ) than for their White counterparts. But, Table 6 shows that, after controlling for other variables, being Black increases the odds of enrolling in a professional degree program for women (odds ratio $=3.95$ ) but is unrelated to the odds of enrolling in a professional degree program for men.

\section{Discussion}

One limitation of this research is that, because of the timing of the second follow-up to the B\&B:93/97, the analyses only examine sex and racial/ethnic group differences in enrollment in a post-baccalaureate program within four to five years of receiving a bachelor's degree. Descriptive analyses of data from the 1996 National Postsecondary Student Aid Study suggest that at least one-half of bachelor's degree recipients enroll in a post-baccalaureate program within four or five years of earning their bachelor's degree (Choy \& Moskovitz, 1998). Of those students who were enrolled in a master's degree program (including an MBA program) in 1995-96, 41\% had enrolled within two years and $71 \%$ had enrolled within six years of receiving their bachelor's degree. About one-half (47\%) of students who were enrolled in doctoral degree programs had enrolled within two years of receiving their bachelor's degree and 70\% had enrolled within six years of receiving their bachelor's degree. Among students enrolled in first-professional degree programs, 
two-thirds (68\%) had enrolled within two years and $86 \%$ had enrolled within seven years (Choy \& Moskovitz, 1998). These descriptive analyses suggest that further research, using a longitudinal database that follows up bachelor's degree recipients after a period longer than four years, is required to more completely examine students' decision to enroll in a post-baccalaureate program.

Despite this limitation, this research forges new theoretical ground by developing a conceptual model that integrates two theoretical perspectives that are typically used in isolation. As suggested by others (Paulsen \& St. John, 2002; Perna, 2000; St. John \& Asker, 2001), the analyses demonstrate the usefulness of an econometric framework that has been expanded to include measures of cultural and social capital as proxies for differences in an individual's preferences, tastes, and expectations for examining sex and racial/ethnic group differences in post-baccalaureate enrollment. Adding measures of cultural and social capital to the model improved several indicators of model fit, including the ratio of scaled deviance to degrees of freedom, the pseudo- $\mathrm{R}^{2}$, and the percentage of cases correctly classified. By incorporating the sociological concepts of cultural and social capital into a traditional econometric approach, this research produced a conceptual framework that better predicts post-baccalaureate enrollment decisions than a traditional econometric approach alone.

As St. John and Asker (2001) argued, this study shows that an integrated approach is particularly important for identifying ways to increase the educational attainment of underrepresented groups. The conceptual model that was developed and tested in this study identifies sources of the observed sex differences in submaster's level and master's degree enrollment and differences in the predictors of post-baccalaureate enrollment for women and men. Although women were observed to be more likely than men to enroll in submaster's level and master's degree programs relative to not enrolling, these differences were explained by sex differences in other variables, particularly starting salary of the undergraduate major field and cumulative undergraduate grade point average. The analyses also revealed that the effects of one measure of foregone earnings (starting salary of the undergraduate major field) and one measure of social capital (Carnegie classification of the undergraduate institution) on post-baccalaureate enrollment were different for women than for men.

More research is required to understand the sources of the lower observed representation of women than men among both doctoral and professional program enrollees and the higher observed representation of Asians among first-professional enrollees. Due to small sample sizes, 
sources of the observed lower enrollment of women than men in doctoral programs could not be explored in this study. Future research should be based on a sample that is sufficiently large to allow an examination of the extent to which the predictors of doctoral degree enrollment vary between women and men of different racial/ethnic groups.

The model that was developed for this study was not able to explain the observed sex gap in professional-degree enrollment. Even after controlling for measures of expected costs and benefits, financial and academic resources, and cultural and social capital, men were more likely than women to enroll in a first-professional degree program by 1997. Although the sex difference in enrollment is not explained by variables in the model, the analyses suggest that the contribution of social capital to enrollment in a first-professional program is different for women than for men. Specifically, the analyses suggest that the social networks and resources that are associated with attending a research I university are particularly important for promoting the enrollment of women in firstprofessional degree programs.

Although the odds of enrolling in a professional degree program relative to not enrolling were observed to be comparable for Blacks and Whites, controlling for measures of financial and academic resources as well as measures of cultural and social capital showed that the odds of enrolling in a professional degree program were higher for Black women than for White women. In other words, Black female bachelor's degree recipients were more likely to enroll in a professional degree program than White female bachelor's degree recipients who were comparable to Black women in terms of all other variables that were included in the analyses. This finding mirrors the finding in some research on racial/ethnic group differences in undergraduate enrollment that Blacks are more likely than Whites to enroll (Catsiapis, 1987; Kane \& Spizman, 1994; Perna, 2000). As noted by others (Hurtado et al., 1997; Perna, 2000), however, this finding should be interpreted with caution since only a small share of Black women are comparable to White women in terms of all other variables that are included in the model. For example, descriptive analyses show that Black women averaged lower cumulative undergraduate grades and lower SAT/ACT scores than White women bachelor's degree recipients. Nearly one-third (30\%) of Black women, but $11 \%$ of White women, bachelor's degree recipients reported cumulative undergraduate grade-point averages no higher than Bs and Cs. Nearly one-half (46\%) of Black women, but only $20 \%$ of White women, had SAT or ACT scores in the lowest quartile.

Future research, including future federally funded longitudinal studies of bachelor's degree recipients, should build on this attempt to oper- 
ationalize the types of cultural and social capital that promote graduate enrollment by developing additional and more appropriate measures. The operationalization of cultural and social capital in this study is limited by the availability of suitable proxies in the B\&B:93/97 database. Most importantly, the database includes no direct measures of the social networks that a bachelor's degree recipient developed as an undergraduate and that may promote graduate enrollment. Social networks may be initiated by the student or by faculty, as perhaps measured by the quantity and quality of interactions with faculty and the characteristics of peer social networks, or initiated by an institution, as might be measured by institutional efforts to inform students about graduate education. Although such structural characteristics of the bachelor's degree-granting institution as Carnegie classification are included as proxies, these measures do not capture the information that bachelor's degree recipients are able to extract from these institutions. Research suggests that informal interactions with peers and faculty are especially important to the graduate enrollment process for men (Ethington \& Smart, 1986). Anecdotal evidence suggests that a university can increase the enrollment of minorities in its graduate programs by informing them of the costs and benefits and encouraging a "taste" for graduate education by proactively "courting" prospective students beginning in the students' junior year of college, conducting summer prematriculation and enrichment programs, and inviting minority applicants for tours of campus (Philip, 1993; Moskowitz, 1994). Such social networks may be particularly helpful in informing prospective students about the ways to improve their applications to graduate programs. A survey of professional programs that were approved by the American Psychological Association in 1984 suggests that many applicants do not know the types of the information that should be included in an application to a doctoral program or that letters of recommendation should focus on academic qualifications (Eddy, Lloyd, \& Lubin, 1987).

Future research should also develop improved measures of an individual's expectations regarding current and future labor market opportunities, opportunities for advancement that may result from graduate education, time needed to complete an advanced degree, and other investments that may be required to achieve future benefits, including the need to accept a postdoctoral research position after completing a doctoral degree. While this research uses the starting salary of the undergraduate major field as a proxy for labor market opportunities, future research should develop measures that more closely reflect the ways in which women and men assess the costs and benefits of pursuing postbaccalaureate education. 


\section{The Journal of Higher Education}

This research contributes to our knowledge of the most appropriate theoretical framework for examining sex and racial/ethnic group differences in post-baccalaureate enrolment. Nonetheless, additional research is required to continue to build our understanding of the explained and unexplained sources of sex and racial/ethnic group differences in professional and doctoral enrollment and the ways in which the post-baccalaureate enrollment process differs between women and men. In the shortterm, such an understanding is a prerequisite to identifying the policies and practices that will most effectively raise graduate and professional school enrollment rates for traditionally underrepresented groups of students. In the long-term, as noted by Björk and Thompson (1989), such an understanding will address one part of the process needed to build a pool of potential faculty that more closely reflects the sex and racial/ethnic diversity of the undergraduate student body. Identifying ways to increase graduate and professional school enrollment will likely lead not to a continued oversupply of highly educated individuals, but to a workforce that is better-prepared to meet the increasingly complex knowledge demands of a global economy (Geiger, 1997).

\section{Notes}

${ }^{1}$ The choice of five years between bachelor's degree and doctoral degree is somewhat arbitrary. As Bowen and Rudenstine (1992) note, doctoral degree recipients in any particular year received their bachelor's degrees in a wide range of preceding years.

${ }^{2}$ Although nonresident aliens comprised only $0.7 \%$ of the $1992-93$ bachelor's degree recipients, they received $25 \%$ of the doctoral degrees that were awarded in 1997-98 (NCES, 2001). This discrepancy suggests that most nonresident aliens entered doctoral programs after completing undergraduate degrees in their home country. An examination of the decision to enroll in a U.S. graduate or professional program among nonresident aliens is not possible with the B\&B:93/97 dataset.

${ }^{3}$ Because of space limitations, tables summarizing the descriptive analyses are not presented here but are available from the author upon request.

\section{References}

Andrieu, S. C., \& St. John, E. P. (1993). The influence of prices on graduate student persistence. Research in Higher Education, 34, 399-419.

Becker, G. S. (1962). Investment in human capital: A theoretical analysis. Journal of Political Economy, 70 Supplement (5), 9-49.

Björk, L. G., \& Thompson, T. E. (1989). The next generation of faculty: Minority issues. Education and Urban Society, 21, 341-351.

Bourdieu, P., \& Passeron, J. C. (1977). Reproduction in education, society and culture. Beverly Hills, CA: Sage Publications.

Bowen, W. G., \& Rudenstine, N. L. (1992). In pursuit of the PhD. Princeton: Princeton University Press. 
Catsiapis, G. (1987). A model of educational investment decisions. Review of Economics and Statistics 69, 33-41.

Choy, S. P., \& Moskovitz, R. (1998). Graduate and first-professional students: National Postsecondary Student Aid Study (NCES 98-139). Washington, DC: U.S. Department of Education, National Center for Education Statistics.

Cohen, J., \& Cohen, P. (1983). Applied multiple regression for the behavioral sciences. Hillsdale, NJ: Erlbaum Associates Publishers.

Coleman, J. S. (1988). Social capital in the creation of human capital. American Journal of Sociology, 94(Supplement), 95-120.

DiMaggio, P., \& Mohr, J. (1985). Cultural capital, educational attainment, and marital selection. American Journal of Sociology, 90, 1231-1261.

Eddy, B., Lloyd, P. J., \& Lubin, B. (1987). Enhancing the application to doctoral professional programs: Suggestions from a national survey. Teaching of Psychology, 14, $160-163$.

Ehrenberg, R. G. (1991). Academic labor supply. In C. T. Clotfelter, R. G. Ehrenberg, M. Getz, \& J. J. Siegfried (Eds.), Economic challenges in higher education (pp. 143-260). Chicago: University of Chicago Press.

Ethington, C. A., \& Smart, J. C. (1986). Persistence to graduate education. Research in Higher Education, 24, 287-303.

Fox, M. (1992). Student debt and enrollment in graduate and professional school. Applied Economics, 24, 669-677.

Geiger, R. (1997). Doctoral education: The short-term crisis vs. long-term challenge. Review of Higher Education, 20, 239-251.

Green, P., Myers, S., Veldman, C., \& Pedlow, S. (1999). Baccalaureate and Beyond Longitudinal Study: 1993/97 second follow-up methodology report (NCES 1999-159). Washington, DC: U.S. Department of Education, Office of Educational Research and Improvement.

Hearn, J. C. (1987). Impacts of undergraduate experiences on aspirations and plans for graduate and professional education. Research in Higher Education, 27, 119-141.

Hurtado, S., Inkelas, K. K., Briggs, C., \& Rhee, B. S. (1997). Differences in college access and choice among racial/ethnic groups: Identifying continuing barriers. Research in Higher Education, 38, 43-75.

Jackson, G. A. (1990). Financial aid, college entry, and affirmative action. American Journal of Education, 523-550.

Kane, J., \& Spizman, L. M. (1994). Race, financial aid awards and college attendance: Parents and geography matter. American Journal of Economics and Sociology, 53, $73-97$.

King, S. E., \& Chepyator-Thomson, J. R. (1996). Factors affecting the enrollment and persistence of African-American doctoral students. Physical Educator, 53, 170-180.

Lamont, M., \& Lareau, A. (1988). Cultural capital: Allusions, gaps and glissandos in recent theoretical developments. Sociological Theory, 6, 153-168.

Lang, D. (1984). Education, stratification, and the academic hierarchy. Research in Higher Education, 21, 329-354.

Lango, D. R. (1995). Mexican American female enrollment in graduate programs: A study of the characteristics that may predict success. Hispanic Journal of Behavioral Sciences, 17, 33-48. 
Malaney, G. D. (1987). Why students pursue graduate education, how they find out about a program, and why they apply to a specific school. College and University, 62, 247-258.

Manski, C. F., \& Wise, D. A. (1983). College choice in America. Cambridge: Harvard University Press.

McCormick, A. C., Nuñez, A. M., Shah, V., \& Choy, S. P. (1999). Life after college: A descriptive summary of 1992-93 bachelor's degree recipients in 1997. Washington, DC: Office of Educational Research and Improvement (NCES 1999-155).

McDonough, P. M. (1997). Choosing colleges: How social class and schools structure opportunity. Albany: State University of New York Press.

McNeal, R. B. (1999). Parental involvement as social capital: Differential effectiveness on science, achievement, truancy, and dropping out. Social Forces, 78, 117-144.

McPherson, M. S., \& Winston, G. C. (1993). The economics of cost, price, and quality in U.S. higher education. Chapter 4 in McPherson, M. O. Shapiro, and G. C. Winston (Eds.), Paying the piper: Productivity, incentives, and financing in U.S. higher education. Ann Arbor: University of Michigan Press.

Morrow, V. (1999). Conceptualising social capital in relation to the well-being of children and young people: A critical review. Sociological Review, 47, 744-765.

Moskowitz, M. (1994). The black medical schools remain the prime training ground for black doctors. Journal of Blacks in Higher Education, 69-76.

National Center for Education Statistics (1998). Condition of education 1998, Indicator 33. Washington, DC: Author. (www.nces.ed.gov/NCES/pubs98/condition98/c9833a01.html)

National Center for Education Statistics (2002). Digest of education statistics 2001. Washington, DC: Office of Educational Research and Improvement (NCES 2002-130).

Paulsen, M. B., \& St. John, E. P. (2002). Social class and college costs: Examining the financial nexus between college choice and persistence. Journal of Higher Education, 73, 189-236.

Peng, C. J., So, T.-S. H., Stage, F. K., \& St. John, E. P. (2002). The use and interpretation of logistic regression in higher education journals. Research in Higher Education, 43, 259-294.

Perna, L. W. (2000). Differences in the decision to enroll in college among African Americans, Hispanics, and Whites. Journal of Higher Education, 71, 117-141.

Perna, L. W. (1998). Does financial aid help students to attend higher priced colleges? Journal of Student Financial Aid, 28, 19-38.

Phillip, M. C. (1993). Enhancing the presence of minorities in graduate schools: What works for some institutions. Black Issues in Higher Education, 10(10), 33-35.

Poock, M. C., \& Love, P. G. (2001). Factors influencing the program choice of doctoral students in higher education administration. NASPA Journal, 38, 203-223.

Portes, A. (1998). Social capital: Its origins and applications in modern sociology. Annual Review of Sociology, 24, 1-24.

Qian, Z., \& Blair, S. L. (1999). Racial/ethnic differences in educational aspirations of high school seniors. Sociological Perspectives, 42, 605-625.

Siegel, S. R., \& Lajmi, R. R. (1999). The impact of an expanding professional contingent labor force on enrollments in MBA programs. C\&U Journal, 75(2), 3-6.

St. John, E. P., \& Asker, E. H. (2001). The role of finances in student choice: A review of 
theory and research. In M. B. Paulsen, \& J. C. Smart (Eds.), The finance of higher education: Theory, research, policy, and practice (pp. 419-438). New York: Agathon Press.

St. John, E. P., \& Noell, J. (1989). The effects of student financial aid on access to higher education: An analysis of progress with special consideration of minority enrollments. Research in Higher Education, 30, 563-581.

St. John, E. P., \& Paulsen, M. B. (2001). The finance of higher education: Implications for theory, research, policy, and practice. In M. B. Paulsen, \& J. C. Smart (Eds.), The finance of higher education: Theory, research, policy, and practice (pp. 545-568). New York: Agathon Press.

Stanton-Salazar, R. D., \& Dornbusch, S. M. (1995). Social capital and the reproduction of inequality: Information networks among Mexican-origin high school students. Sociology of Education, 68, 116-135.

Stiber, G. F. (2000). Characterizing the decision process leading to enrollment in doctoral programs: Theory, application, and practice. Journal of Marketing for Higher Education, 10, 13-26.

Thomas, S. L., \& Heck, R. H. (2001). Analysis of large-scale secondary data in higher education research: Potential perils associated with complex sampling designs. Research in Higher Education, 42, 517-540.

Weiler, W. C. (1991). The effect of undergraduate student loans on the decision to pursue postbaccalaureate study. Educational Evaluation and Policy Analysis, 13, 212-220. 